\title{
Chimeric Derivatives of Functionalized Amino Acids and a- Aminoamides: Compounds with Anticonvulsant Activity in Seizure Models and Inhibitory Actions on Central, Peripheral, and Cardiac Isoforms of Voltage-gated Sodium Channels
}

\author{
Robert Torregrosa ${ }^{1}$, Xiao-Fang Yang ${ }^{2}$, Erik T. Dustrude ${ }^{3}$, Theodore R. Cummins ${ }^{3,4}$, Rajesh \\ Khanna ${ }^{2}$, and Harold Kohn ${ }^{1,5,6}$ \\ ${ }^{1}$ NeuroGate Therapeutics, Inc., 150 Fayetteville Street, Suite 2300, Raleigh, NC 27601 \\ ${ }^{2}$ Department of Pharmacology and Neuroscience Graduate Interdisciplinary Program, College of \\ Medicine, University of Arizona, Tucson, Arizona 85742, United States \\ ${ }^{3}$ Program in Medical Neuroscience, Paul and Carole Stark Neurosciences Research Institute, \\ Indiana University School of Medicine, Indianapolis, IN 46202 \\ ${ }^{4}$ Department of Pharmacology and Toxicology, Indiana University School of Medicine, \\ Indianapolis, IN 46202 \\ ${ }^{5}$ Division of Chemical Biology and Medicinal Chemistry, UNC Eshelman School of Pharmacy, \\ University of North Carolina, Chapel Hill, NC 27599, United States \\ ${ }^{6}$ Department of Chemistry, University of North Carolina, Chapel Hill, NC 27599, United States
}

\section{Abstract}

Six novel 3"-substituted ( $R$ )- $N$-(phenoxybenzyl) 2- $N$-acetamido-3-methoxypropionamides were prepared and then assessed using whole-cell, patch-clamp electrophysiology for their anticonvulsant activities in animal seizure models and for their sodium channel activities. We found compounds with various substituents at the terminal aromatic ring that had excellent anticonvulsant activity. Of these compounds, $(R)-N-4^{\prime}-\left(\left(3^{\prime \prime}-\right.\right.$ chloro)phenoxy)benzyl 2-Nacetamido-3-methoxypropionamide $((R)-5)$ and $(R)-N-4^{\prime}-\left(\left(3^{\prime \prime}\right.\right.$-trifluoromethoxy)phenoxy)benzyl 2- $N$-acetamido-3-methoxypropionamide $((R)-9)$ exhibited high protective indices (PI $=\mathrm{TD}_{50} /$ $\mathrm{ED}_{50}$ ) comparable with many antiseizure drugs when tested in the maximal electroshock seizure test to mice (intraperitoneally) and rats (intraperitoneally, orally). Most compounds potently transitioned sodium channels to the slow-inactivated state when evaluated in rat embryonic

\footnotetext{
(C) 2015 Published by Elsevier Ltd.

Correspondence to: Rajesh Khanna; Harold Kohn.

Supporting data

Synthetic procedures, experimental and spectral data for the intermediates and final products evaluated in this study including tables for elemental analyses and high-resolution MS data; and ${ }^{1} \mathrm{H}$ NMR and ${ }^{13} \mathrm{C}$ NMR spectra for $(R)-\mathbf{3},(R)-\mathbf{5}-(R)-\mathbf{9}$. This material is available free of charge via the Internet at http://dx.doi.org.

Publisher's Disclaimer: This is a PDF file of an unedited manuscript that has been accepted for publication. As a service to our customers we are providing this early version of the manuscript. The manuscript will undergo copyediting, typesetting, and review of the resulting proof before it is published in its final citable form. Please note that during the production process errors may be discovered which could affect the content, and all legal disclaimers that apply to the journal pertain.
} 
cortical neurons. Treating HEK293 recombinant cells that expressed $\mathrm{hNa}_{\mathrm{v}} 1.1, \mathrm{rNa}_{\mathrm{v}} 1.3, \mathrm{hNa}_{\mathrm{v}} 1.5$, or $\mathrm{hNa}_{\mathrm{v}} 1.7$ with $(R)-9$ recapitulated the high levels of sodium channel slow inactivation.

\section{Keywords}

Chimeric agents; functionalized amino acids; a-aminoamides; antiseizure agents; $\mathrm{Na}^{+}$current inhibition

\section{Introduction}

The epilepsies are serious, neurological disorders that affect up to $1 \%$ of the world's population. ${ }^{1}$ Although more than 40 drugs have been used to treat these disorders, ${ }^{2}$ significant health needs remain unmet. First, current antiseizure drugs (ASDs) are ineffective for about one-third of patients, even when multiple drugs are prescribed. ${ }^{3}$ Second, ASD use is associated with untoward side effects in more than $40 \%$ of patients, ranging from common cosmetic (e.g., gingival hyperplasia, weight gain) and quality of life (e.g., sedation, learning, cognitive dysfunction) to rare, life-threatening (e.g., hepatotoxicity, aplastic anemia) ones. ${ }^{4,5}$ Third, some epilepsies, such as Lenox-Gestault and mesial temporal lobe epilepsy, worsen over time, and for these disorders, there is a need for a disease-modifying drug. ${ }^{6}$ Finally, most seizure medications do not address associated comorbidities (e.g., cognitive dysfunction ${ }^{7}$ ). Thus, the need still remains for ASDs that have novel mechanism(s) of action with safe profiles.

We have reported on a novel series of chimeric compounds, $(R)-\mathbf{A},{ }^{8-10}$ derived from the merger of key structural units (Fig. 1B, C) present in the functionalized amino acid (FAA), lacosamide ${ }^{11}((R)-N$-benzyl 2- $N$-acetamido-3-methoxypropionamide, $(R)-\mathbf{1})$ and the aaminoamide (AAA), safinamide ${ }^{12,13}\left((S)-2-\left(4^{\prime}-\left(\left(3^{\prime \prime}-\right.\right.\right.\right.$

fluoro)benzyloxy)benzyl)aminopropionamide, $(S)$-2). Lacosamide is a first-in-class ASD that is extensively used for the treatment of partial-onset seizures in adults. ${ }^{14}$ Safinamide, another anticonvulsant, ${ }^{15}$ has been advanced for the treatment of Parkinson's disease. ${ }^{16}$ Studies have shown that safinamide inhibits monoamine oxidase type $B,{ }^{17}$ thus likely preventing dopamine bioactivation in patients suffering from Parkinson's disease. We demonstrated that select $(R)$-A compounds displayed potent anticonvulsant activities in the maximal electroshock ${ }^{18}$ (MES) and the $6-\mathrm{Hz}$ psychomotor ${ }^{19}$ seizure assays in rodents. ${ }^{8-10}$ The anticonvulsant activities of $(R)$-A have been attributed, in part, to their actions on voltage-gated sodium channel (VGSC) properties. ${ }^{9,10,20}$ Chimeric compounds $(R)$-A potently transitioned VGSCs to the slow-inactivated state and in some cases, affected fast inactivation processes and inhibited $\mathrm{Na}^{+}$currents in a frequency (use)-dependent fashion. The experimental findings for slow inactivation by $(R)$-A were also consistent with a mechanism in which the chimeric compounds block fast-inactivated channels with very slow kinetics. $^{21,22}$

An initial structure-activity relationship (SAR) study of $(R)$-A showed excellent anticonvulsant activities for compounds in which the two aryl units were in spatial proximity. ${ }^{8}$ Thus, we further investigated the activities of $(R)$-A compounds wherein the linker (L) was either a single bond ${ }^{9}$ or an oxymethylene $\left(\mathrm{OCH}_{2}\right)^{10}$ group and found that the 
$\mathrm{X}$-substituent in the terminal aromatic ring influenced the cellular and whole animal pharmacological activities. Here, we explore the $(R)$-A series that contain an oxy $(\mathrm{O})$-linker to give $(R)$-D. We demonstrate in seizure models that most X-substituents in $(R)$-D yielded compounds with excellent anticonvulsant activities and minimal neurotoxicities, comparable with many ASDs. Electrophysiology studies showed that $(R)$-D displayed sodium channel properties consistent with other members of this general class of compounds. ${ }^{9,10,20}$<smiles>[X]c1cccc(Oc2ccc(CNC(=O)[C@H](COC)NC(C)=O)cc2)c1</smiles>

(R)-D

\section{Results}

\subsection{Selection of compounds}

We prepared compounds $(R)-3$ and $(R)-5-(R)-9$ where an oxygen was the linker $(\mathrm{L})$ between the two aromatic rings. Our initial SAR study documented that $(R)-\mathbf{4}$, the $3^{\prime \prime}$ fluorine $(R)$-D derivative, exhibited pronounced anticonvulsant activity in rodents. ${ }^{8}$

Accordingly, we restricted the site of substitution on the terminal aromatic ring to the $3^{\prime \prime}$ position. The X-substituent ranged from electron-withrawing to electron-donating groups.<smiles>[X]c1cccc(Oc2ccc(CNC(=O)[C@H](COC)NC(C)=O)cc2)c1</smiles>

$(R)-3 ; \quad \mathrm{X}=\mathrm{H}$

$(R)-4 ; \quad \mathrm{X}=\mathrm{F}$

$(R)-5 ; \quad \mathrm{X}=\mathrm{Cl}$

$(R)-6 ; \quad \mathrm{X}=\mathrm{CH}_{3}$

$(R)-7 ; \quad \mathrm{X}=\mathrm{CF}_{3}$

$(R)-8 ; \quad \mathrm{X}=\mathrm{OCH}_{3}$

$(R)-9 ; \quad \mathrm{X}=\mathrm{OCF}_{3}$

\subsection{Synthesis}

Compounds $(R)-\mathbf{3}$ and $(R)-\mathbf{5}-(R)-\mathbf{9}$ were prepared by a similar route (Scheme 1), using the mixed anhydride coupling (MAC) method. ${ }^{23}$ Commercially available $(R)$-N-tert-

butoxycarbonyl-D-serine $((R)-27)$ was coupled with the 4-(phenoxy)phenylmethamines 21 - 
26 using the MAC reagents isobutylchloroformate (IBCF) and $N$-methylmorpholine (NMM) to give amides $(R)-\mathbf{2 8}-(R)-\mathbf{3 3}$, respectively, without racemization of the $\mathrm{C}(2)$ chiral center. The substituted 4-phenoxybenzylamines were prepared by treating 4-fluorobenzonitrile (10) with the appropriate aryl phenol (11 - 15) using either $\mathrm{K}_{2} \mathrm{CO}_{3}$ or $\mathrm{Cs}_{2} \mathrm{CO}_{3}$ in DMF to give the corresponding nitriles. ${ }^{24-27}$ Subsequent reduction of the nitrile group in $\mathbf{1 6 - 2 0}$ with $\mathrm{LiAIH}_{4}$ afforded the amines $\mathbf{2 2} \mathbf{- 2 6}$. The corresponding unsubstituted 4phenoxybenzylamine (21) was commercially available. Methylation $\left(\mathrm{CH}_{3} \mathrm{I}, \mathrm{Ag}_{2} \mathrm{O}\right)$ of the serine hydroxyl group in $(R)-\mathbf{2 8}-(R)-33$ provided ethers $(R)-34-(R)-39$, respectively. Deprotection of the tert-butoxycarbonyl group in $(R)-\mathbf{3 4}-(R)-39$ with acid (HCI/dioxane) followed by acetylation ( $\mathrm{AcCI}_{1} \mathrm{Et}_{3} \mathrm{~N}$ ) gave the desired products $(R)-\mathbf{3}$ and $(R)-\mathbf{5}-(R)-\mathbf{9}$, respectively. The enantiomeric purities of $(R)-\mathbf{3}$ and $(R)-\mathbf{5}-(R)-\mathbf{9}$ were assessed by the detection of a single acetyl methyl peak and a single $O$-methyl peak in the ${ }^{1} \mathrm{H}$ NMR spectrum for each compound when a saturated solution of $(R)-(-)$-mandelic acid was added. ${ }^{28}$

We report, in the Experimental Section, the details (synthetic procedure, characterization) of the final step for all compounds evaluated in the seizure and cellular electrophysiology studies. In the Supporting Information, we provide the experimental procedures and the physical and full spectroscopic properties for all the synthetic compounds prepared in this study.

\subsection{Pharmacological evaluation}

2.3.1. Whole animal pharmacological activity-Compounds $(R)-3$ and $(R)-5-(R)-9$ were tested for anticonvulsant activity at the Anticonvulsant Screening Program (ASP) of the National Institute of Neurological Disorders and Stroke (NINDS), U.S. National Institutes of Health, using the procedures described by Stables and Kupferberg. ${ }^{29}$ The anticonvulsant data from the MES model ${ }^{18}$ (mice, intraperitoneally (ip); rat, ip; rat, orally (po)), and the psychomotor $6 \mathrm{~Hz}\left(32 \mathrm{~mA}\right.$ ) seizure test for therapy-resistant limbic seizures ${ }^{19}$ (mice, ip) are summarized in Table 1 along with similar results (where available) obtained for $(R)-\mathbf{1},{ }^{11,30}(S)-\mathbf{2},{ }^{15}$ and $(R)-\mathbf{4},{ }^{8}$ and the ASDs phenytoin,,${ }^{31,32}$ phenobarbital, ${ }^{31}$ and valproate. ${ }^{31}$ For compounds that showed significant activity, we report the $50 \%$ effective dose $\left(\mathrm{ED}_{50}\right)$ values from quantitative screening evaluations. We also include the median doses for $50 \%$ neurological impairment $\left(\mathrm{TD}_{50}\right)$ in mice, using the rotorod test, ${ }^{33}$ and the behavioral toxicity effects observed in rats. ${ }^{34}$ The protective index $\left(\mathrm{PI}=\mathrm{TD}_{50} / \mathrm{ED}_{50}\right)$ for the test compounds is listed, where possible. Compounds $(R)-\mathbf{4}-(R)-\mathbf{6},(R)-\mathbf{8}$ and $(R)-\mathbf{9}$ were evaluated in the subcutaneous Metrazol (scMet) seizure model, ${ }^{35}$ and no activity was observed below $40 \mathrm{mg} / \mathrm{kg}$ (data not shown). Similarly, we found no activity in the scMet model for $(R)-\mathbf{1}^{11}$ and structurally related compounds. ${ }^{8-10,36}$

Compounds $(R)-\mathbf{3}-(R)-\mathbf{9}$ displayed excellent activities in the MES model in mice when administered ip and in rats when administered either ip or po. For most compounds, we observed in mice (ip) $\mathrm{ED}_{50}$ values that ranged from $5.5-14 \mathrm{mg} / \mathrm{kg}$, values that were comparable with the ASDs $(R)-\mathbf{1}^{11}$ and phenytoin ${ }^{31,32}\left(\mathrm{ED}_{50}(\mathrm{mg} / \mathrm{kg}):(R)-\mathbf{3},>10,<30\right.$; $(R)-4,5.5 ;(R)-5,9.4 ;(R)-6,14 ;(R)-7, \sim 10 ;(R)-8,13 ;(R)-9 ; 6.5 ;(R)-1,4.5$; phenytoin, 9.5). Furthermore, we found that many of the compounds exhibited low neurotoxicities in the 
rotorod test in mice (ip), thus affording high PI values similar to $(R)-\mathbf{1}^{11}$ and phenytoin ${ }^{31,32}$ (PI: $(R)-\mathbf{4}, 4.2 ;(R)-\mathbf{5}, 5.0 ;(R)-\mathbf{6}, 4.6 ;(R)-\mathbf{8}, 6.5 ;(R)-\mathbf{9}, 6.2 ;(R)-\mathbf{1}, 6.0$; phenytoin, 6.9). In rats (po), excellent activities were observed for $(R)-\mathbf{5}$ and $(R)-\mathbf{9}\left(\mathrm{ED}_{50}(\mathrm{mg} / \mathrm{kg}):(R)-\mathbf{5}, 12 ;(R)-\mathbf{9}\right.$, 8.3). The PI values for these compounds were high but were lower than $(R)-\mathbf{1}$ and phenytoin (PI: $(R)-\mathbf{5}, 18 ;(R)-\mathbf{9}, 29 ;(R)-\mathbf{1},>130$; phenytoin, $>36)$. In rats (ip), $(R)-\mathbf{5},(R)-\mathbf{6},(R)-\mathbf{8}$, and $(R)-9$ displayed potent activities ( $\mathrm{ED}_{50}$ values: $5.7-15 \mathrm{mg} / \mathrm{kg}$ ) and low neurotoxicities (TD 50 values: $49-140 \mathrm{mg} / \mathrm{kg}$ ) giving PI values that ranged from 8.0-12, values higher than phenytoin $^{32}$ (PI: $(R)-\mathbf{5}, 8.3 ;(R)-6,12 ;(R)-8,8.0 ;(R)-\mathbf{9}, 9.5$; phenytoin, 6.3). Finally, we evaluated $(R)-3-(R)-\mathbf{9}$ in the $6 \mathrm{~Hz}(32 \mathrm{~mA})$ psychomotor seizure test and found that $(R)-\mathbf{4}$, $(R)-\mathbf{5}$, and $(R)-\mathbf{9}$ were the most active compounds $\left(\mathrm{ED}_{50}(\mathrm{mg} / \mathrm{kg}):(R)-\mathbf{4}, \sim 10 ;(R)-\mathbf{5}, 20\right.$; $(R)-\mathbf{9}, 15)$. By comparison, the $6 \mathrm{~Hz}^{\mathrm{E}} \mathrm{ED}_{50}$ value for $(R)-\mathbf{1}$ was $10 \mathrm{mg} / \mathrm{kg} .{ }^{30}$

2.3.2. Whole-cell, patch-clamp electrophysiological activity-The well-described mechanisms of action by lacosamide and safinamide, parents of $(R)$-D series compounds, both involve inhibition of VGSCs. ${ }^{14,15,37,38}$ Promising anticonvulsant activities of $(R)$-3 $(R)-9$ therefore prompted our examination of the VGSC activities in rat embryonic cortical neurons ${ }^{9,10,39}$ by whole-cell, patch-clamp electrophysiology. These neurons typically express central nervous system (CNS) sodium channel isoforms $\mathrm{Na}_{\mathrm{v}} 1.1, \mathrm{Na}_{\mathrm{v}} 1.2, \mathrm{Na}_{\mathrm{v}} 1.3$, and $\mathrm{Na}_{\mathrm{v}}$ 1.6. ${ }^{40}$ Kinetic properties of slow inactivation, frequency (use)-dependence, and steady-state activation and fast inactivation of $\mathrm{Na}^{+}$currents were measured in the presence of $(R)-3-(R)-9$. The cortical neurons were grown for 7-10 days in vitro and then examined using protocols described earlier. ${ }^{9,10,39}$ Compounds $(R)-3-(R)-\mathbf{9}$ were tested only at $10 \mu \mathrm{M}$ due to constraints of cortical neuron viability during the course of the patch-clamp experiments. Here, we did not separate the exact contribution of the four $\mathrm{Na}_{\mathrm{v}}$ isoforms in the presence of $(R)-3-(R)-9$ because of the lack of subtype-specific blockers of these $\mathrm{Na}_{\mathrm{V}}$ isoforms, and the possible interactions between said blockers of various $\mathrm{Na}_{\mathrm{v}}$ channels and the (R)-D compounds themselves. Thus, we assumed contributions from all four CNS $\mathrm{Na}_{\mathrm{v}}$ isoforms. The excellent anticonvulsant activity observed for $(R)-9$ led us to examine this compound further in both catecholamine A-differentiated (CAD) cells ${ }^{41}$ that express predominantly $\mathrm{Na}_{\mathrm{v}} 1.7$ and in recombinant HEK293 cells that express $\mathrm{hNa}_{\mathrm{v}} 1.1, \mathrm{rNa}_{\mathrm{v}} 1.3$, $\mathrm{hNa}_{\mathrm{v}} 1.5$, or $\mathrm{hNa}_{\mathrm{v}} 1.7$ channels. ${ }^{9}$

2.3.2.1. Rat embryonic cortical neurons: First, we tested the ability of $10 \mu \mathrm{M}(R)-3-(R)-9$ to modulate the transition of VGSCs to a slow-inactivated state. Cortical cells were conditioned to potentials ranging from $-100 \mathrm{mV}$ to $+20 \mathrm{mV}$ (in $+10 \mathrm{mV}$ increments) for 5 s. $9,39,42$ Channels that underwent fast inactivation during this conditioning pulse were then allowed to recover during a 1 second pulse to $-70 \mathrm{mV}$ before the extent of slow inactivation was examined by a test pulse to $-10 \mathrm{mV}$, for $20 \mathrm{~ms}$ (Fig. 2A, left). Representative traces illustrating the extent of slow inactivation observed at $-50 \mathrm{mV}$ compared to the prepulse at $-100 \mathrm{mV}$ in the absence (control) or presence of $(R)-\mathbf{5}$ and $(R)-\mathbf{8}$ are shown in Figure 2A $(r i g h t)$, with the full slow inactivation curve (normalized peak versus prepulse potential) of $(R)-5$ shown in Figure 2B. At $10 \mu \mathrm{M},(R)-5$ facilitated the transition of a majority of sodium channels into the slow-inactivated state compared with control (0.1\% DMSO)-treated neurons. Slow inactivation at $-50 \mathrm{mV}$ was chosen as a point of comparison between compounds due to the physiological relevance of this voltage near the resting membrane 
potential and action potential firing threshold of neruons. At this voltage, VGSC activation and inactivation kinetics mediate channel availability that determines if sustained firing, akin to that during an epileptic event, is possible. ${ }^{43-47} \mathrm{At}-50 \mathrm{mV}$, a small fraction (i.e., 0.16 $\pm 0.05 \mathrm{n}=5$; calculated as 1 minus the normalized $\mathrm{I}_{\mathrm{Na}}$ ) of the channels had entered a slowinactivated conformational state(s) in control-treated cells (Fig. 2B, C). Compared with the control, $(R)-\mathbf{3}-(R)-\mathbf{9}$ caused a significant decrease in the maximal fraction of current that is available by depolarization, with maximal induction observed in the presence of $(R)-\mathbf{3}(0.82$ $\pm 0.03, \mathrm{n}=5)(\mathrm{p}<0.01$, Mann-Whitney $\mathrm{U}$ test $)$.

We next interrogated if $(R)-\mathbf{3}-(R)-\mathbf{9}$ could enhance steady-state fast inactivation. For these studies we used a similar protocol (Fig. 3, top left) designed to induce a fast-inactivated state. ${ }^{9}$ Cells were subjected to inactivating prepulse potentials ranging from -100 to $-10 \mathrm{mV}$ (in $10-\mathrm{mV}$ increments) for $500 \mathrm{~ms}$ prior to a $0 \mathrm{mV}$ test pulse for $20 \mathrm{~ms}$ to estimate the extent of fast inactivation. The $500 \mathrm{~ms}$ conditioning pulse allows for examination of the linear range of fast inactivation curves for endogenous channels at assayed potentials. Steady-state, fast inactivation curves of $\mathrm{Na}^{+}$currents from control (0.1\% DMSO)- and $(R)-3$ - $(R)-\mathbf{9}$ treated cortical neurons were well fitted with a single Boltzmann function $\left(\mathrm{R}^{2}>0.963\right.$ for all conditions). The value of voltage of half-maximal inactivation $\left(V_{1 / 2}\right)$ for $0.1 \%$ DMSOtreated cells was $-53.4 \pm 1.5 \mathrm{mV}(\mathrm{n}=4)$, which was not significantly different from that observed for $(R)-\mathbf{3}-(R)-\mathbf{9}$ (p>0.05 vs. control; Student's $t$-test; Fig. 3).

Next, we tested whether $(R)-\mathbf{3}-(R)-\mathbf{9}$ could alter the voltage-dependence of activation for cortical neuron VGSCs. Activation changes for cortical neurons treated with compounds were measured by whole-cell ionic conductances in response to changes in command voltage (Fig. 3, top right) and analyzed by comparing Boltzmann properties of half maximal activation $\left(V_{l / 2}\right)$ and slope factors $(k) .{ }^{9}, 39$ Boltzmann fits for $0.1 \%$ DMSO (control) and $(R)-\mathbf{3}-(R)-\mathbf{9}$ are shown in Figure 3. The $V_{1 / 2}$ value for steady-state activation for $0.1 \%$ DMSO-treated (control) neurons was $-27.1 \pm 1.3 \mathrm{mV}(\mathrm{n}=5)$, which was significantly different from that of $(R)-7(-35.6 \pm 4.1 \mathrm{mV} ; \mathrm{n}=5)$ and $(R)-8(-36.8 \pm 1.0 \mathrm{mV} ; \mathrm{n}=6)(\mathrm{p}<0.05$ vs. control; Student's $t$-test; Fig. 3) but not for $(R)-\mathbf{3}-(R)-\mathbf{6}$ and $(R)-\mathbf{9}$.

Finally, we tested if $(R)-3-(R)-9$ could elicit frequency (use)-dependent blockage of $\mathrm{Na}^{+}$ currents. The ability to block $\mathrm{Na}^{+}$currents in an activity- or use-dependent manner is a useful property for ASDs since it allows for preferential decreases in sodium channel availability during high- (i.e., seizures) but not low-frequency firing. ${ }^{48}$ Thirty, identical test pulses were applied at $10 \mathrm{~Hz}$ (Fig. 4A). ${ }^{9,39}$ The difference in available current was calculated by dividing the peak current at any given pulse ( pulse $_{\mathrm{N}}$ ) by the peak current in response to the initial pulse (pulse $)_{1}$ ). Representative currents for this protocol are shown for control and $10 \mu \mathrm{M}(R)-7$-treated cells (Fig. 4B). None of the tested compounds exhibited statistically relevant frequency (use)-dependent inhibition of $\mathrm{Na}^{+}$currents (Fig. 4C).

The anticonvulsant activity for $(R)-9$ led us to further explore the electrophysiological properties of this compound in CAD and HEK293 recombinant cells, which express a distinct population of $\mathrm{Na}_{\mathrm{v}}$ channels. 
2.3.2.2. CAD cells: CAD cells express endogenous tetrodotoxin-sensitive $\mathrm{Na}^{+}$currents that display rapid activation and inactivation kinetics upon membrane depolarization ${ }^{39}$ and are likely composed mostly of $\mathrm{Na}_{\mathrm{v}} 1.7$ channels with minor contributions by $\mathrm{Na}_{\mathrm{v}} 1.1, \mathrm{Na}_{\mathrm{v}} 1.3$, and $\mathrm{Na}_{\mathrm{v}} 1.9$ channels. ${ }^{9,42,49}$ We showed that the sodium channel properties of $(R)-\mathbf{1}$ in CAD cells ${ }^{49}$ are similar to those in cultured neurons and in mouse N1E-115 neuroblastoma cells. ${ }^{50} \mathrm{CAD}$ cells were easily recorded from and cultured thus allowing us to conveniently determine $(R)-9$ sodium channel slow inactivation, frequency (use)-dependence, and steadystate activation and fast inactivation properties over a range of concentrations. These properties were quantitatively compared with other $(R)$-A compounds, $(R)-\mathbf{1}$, and $(S)-\mathbf{2}$. Compound $(R)-\mathbf{9}$ promoted VGSC transition to a slow-inactivated state in a concentrationdependent manner; almost complete slow inactivation was observed at the highest concentration (Fig. 5A). To determine the comparative level to which $(R)-9$ induced slow inactivation, we calculated concentration response curves for slow inactivation induction at $-50 \mathrm{mV}$ as well as at $+20 \mathrm{mV}$; the $\mathrm{IC}_{50}$ inactivation values are shown in Figure $5 \mathrm{~A}$ (boxes). Compared with our recently reported $\mathrm{IC}_{50}$ values of 85 and $13 \mu \mathrm{M}$ for slow inactivation induced by $(R)-\mathbf{1}^{9,20}$ and $(S)-\mathbf{2},{ }^{10}$ the $\mathrm{IC}_{50}$ value for $(R)-\mathbf{9}(0.70 \mu \mathrm{M})$ was $\sim 121$-fold and $\sim 19$ fold lower, respectively, at $-50 \mathrm{mV}$. Similar differences in the $\mathrm{IC}_{50}$ values were measured at $+20 \mathrm{mV}$. Next, we tested for the effects of $(R)-\mathbf{9}$ on fast inactivation. We used a protocol tailored to induce a fast-inactivated state, as previously described. ${ }^{9,10,20}$ Cells were subjected to prepulse potentials ranging from -120 to $-10 \mathrm{mV}$ in $10 \mathrm{mV}$ increments for 500 $\mathrm{ms}$. A $0 \mathrm{mV}$ test pulse for $20 \mathrm{~ms}$ measures the available current. The $500 \mathrm{~ms}$ conditioning pulse allows for examination of the linear range of fast inactivation curves for endogenous channels at assayed potentials. As illustrated in Figure 5B, steady-state, fast inactivation curves of $\mathrm{Na}^{+}$currents from control ( $0.1 \%$ DMSO) and CAD neurons treated with various concentrations of $(R)-9$ were well fitted with a single Boltzmann function $\left(\mathrm{R}^{2}>0.979\right.$ for all conditions). The $V_{1 / 2}$ value for inactivation for $0.1 \%$ DMSO (control)-treated cells was $-69.1 \pm 3.6 \mathrm{mV}(\mathrm{n}=7)$, which was significantly different from that of $(R)-9(10 \mu \mathrm{M})$-treated cells $(-84.6 \pm 1.6 \mathrm{mV} ; \mathrm{n}=6 ; \mathrm{p}<0.05$; Student's $t$-test; Fig. $5 \mathrm{~B})$. Because changes in $\mathrm{Na}^{+}$ current amplitudes could be due to alterations in channel gating, ${ }^{51}$ we tested if $(R)$-9 altered the voltage-dependent activation properties of $\mathrm{Na}^{+}$currents. Activation changes for CAD cells treated with $(R)-9$ were measured by whole-cell ionic conductances in response to changes in command voltage and analyzed by comparing Boltzmann properties of midpoints $\left(V_{1 / 2}\right)$ and slope factors $(k)$. We found that VGSC steady-state activation properties were no different between 0.1\% DMSO (control; $V_{1 / 2}$ for activation $=-19.5 \pm 2.8 \mathrm{mV}(\mathrm{n}=8)$ ) and any concentration tested for $(R)-\mathbf{9}$ (Fig. 5B). Finally, we tested if $(R)-\mathbf{9}$ could confer frequency (use)-dependent $\mathrm{Na}^{+}$current block. Thirty, identical test pulses were applied at 10 $\mathrm{Hz}$ as described previously. ${ }^{9,10,20}$ The available current in control cells (0.1\% DMSO) and treated cells (various concentrations of $(R)-9$ ) was calculated by dividing the peak current at any given pulse (pulse $\mathrm{N}_{\mathrm{N}}$ ) by the peak current in response to the initial pulse (pulse ${ }_{1}$ ).

Compound ( $R$ )-9 exhibited frequency (use)-dependent inhibition of $\mathrm{Na}^{+}$currents (Fig. 5C), and by the last pulse, compared with control (0.1\% DMSO), the peak current was $~ 39 \%$ lower in the presence of $10 \mu \mathrm{M}(R)-\mathbf{9}$. When we tested $30 \mu \mathrm{M}(R)-\mathbf{1 0}$ in a similar protocol, we observed $\sim 44 \%$ inhibition in $\mathrm{Na}^{+}$currents (data not shown).

Bioorg Med Chem. Author manuscript; available in PMC 2016 July 01. 
2.3.2.3. HEK293 Recombinant cells: In order to test if $(R)-9$ had effects on various sodium channel isoforms, we examined the effects of $10 \mu \mathrm{M}(R)-\mathbf{9}$ on slow inactivation, fast inactivation, steady-state activation, and frequency (use)-dependence in HEK293 cells that stably expressed CNS $\left(\mathrm{hNa}_{\mathrm{v}} 1.1, \mathrm{rNa}_{\mathrm{v}} 1.3\right)$, peripheral nervous system $\left(\mathrm{hNa}_{\mathrm{v}} 1.7\right)$, and cardiac $\left(\mathrm{hNa}_{\mathrm{v}} 1.5\right)$ channels using voltage protocols ${ }^{9}$ illustrated in Figure 6A, K. The results of these experiments are summarized in Table 2. Notably, $(R)-9$ exhibited similar, though not identical, effects on these biophysical properties irrespective of sodium channels, indicating that this compound exhibited little isoform specificity. We observed that $(R)-9$ robustly transitioned the four sodium channel subtypes to the slow-inactivated state; that $(R)-\mathbf{9}$ shifted the $V_{1 / 2}$ of fast inactivation for $\mathrm{Na}_{\mathrm{v}} 1.7$ by $\sim 20.2 \mathrm{mV}$ in the hyperpolarizing directon without affecting $V_{1 / 2}$ values for any of the other channel isoforms; and that $(R)-9$ had no effect on steady-state activation or on frequency (use)-inhibition of $\mathrm{Na}^{+}$currents carried by any of the $\mathrm{Na}_{\mathrm{v}} 1 . \mathrm{x}$ channels.

2.3.3. Additional studies-Among the $(R)$-D compounds, $(R)-9$ exhibited the most attractive anticonvulsant profile and potently inhibited sodium channel function. Accordingly, we conducted additional tests on this chimeric compound. The observed anticonvulsant activity for $(R)-9$ was further supported by its activities in the psychomotor 6 $\mathrm{Hz}$ test $\left(44 \mathrm{~mA}\right.$ ) for therapy-resistant limbic seizures ${ }^{19}$ (mouse, ip; $\mathrm{ED}_{50}=44 \mathrm{mg} / \mathrm{kg}$ at 0.5 $\mathrm{h}$ ), the corneal kindled seizure model ${ }^{52}$ (mouse, ip; $\mathrm{ED}_{50}=41 \mathrm{mg} / \mathrm{kg}$ at $0.25 \mathrm{~h}$ ), and the rat hippocampal kindled seizure test for partial complex seizures or temporal lobe seizures ${ }^{53,54}$ (rat, ip; $\mathrm{ED}_{50}=22 \mathrm{mg} / \mathrm{kg}$ ). Significantly, the $6 \mathrm{~Hz}(44 \mathrm{~mA})$ test is a model for pharmacoresistant seizures, ${ }^{19,55}$ and the mouse corneal kindling and the rat hippocampal tests are considered to be predicative models for partial-onset and partial complex seizures. ${ }^{52}$

Next, we evauated $(R)-9(10 \mu \mathrm{M})$ against a panel of seven human CYP450 enzymes and observed little or no direct inhibition for CYP1A2, CYP2B6, CYP2C8, CYP2C9, CYP2C19, CYP2D6 and CYP3A4/5 (data not shown). We found little or no time-dependent inhibition of these enzymes other than for CYP2C 8 by $(R)-9$, for which there was an $\sim 16 \%$ inhibition increase after a 30-min preincubation period. We also determined the pharmacokinetic properties for $(R)-\mathbf{9}$ in Sprague-Dawley rats (iv, po). Using a single iv dose of $5 \mathrm{mg} / \mathrm{kg}$ and an oral dose of $20 \mathrm{mg} / \mathrm{kg},(R)-\mathbf{9}$ showed excellent bioavailability (92\%) and where the $\mathrm{t}_{1 / 2}$ (iv) value was $1.75 \mathrm{~h}$, the $\mathrm{t}_{1 / 2}$ (po) value was $4.63 \mathrm{~h}$, and the brain:plasma ratio was $1.2: 1$ at $6.0 \mathrm{~h}$.

Compound $(R)-9$ was evaluated at UNC's NIMH Psychoactive Drug Screening Program (PDSP $)^{56}$ against a battery of 43 receptors known to adversely impact drug effectiveness. No significant binding was observed at $10 \mu \mathrm{M}$. Moreover, $(R)-9$ did not affect hERG $\mathrm{K}^{+}$ channel activity (Patch Express) at $30 \mu \mathrm{M}$ (data not shown). Finally, we conducted a nonGLP 7-day repeated dose toxicity study for $(R)-9$ in Sprague-Dawley female rats upon oral (gavage) administration at 20,60, and $180 \mathrm{mg} / \mathrm{kg} /$ day dose levels. The no observed adverse effect level (NOAEL) for $(R)-9$ was $60 \mathrm{mg} / \mathrm{kg} / \mathrm{day}$, providing a NOAEL/MES $\mathrm{ED}_{50}$ value of $\sim 10$. At higher dose levels, effects were observed in the ability to bear weight, coordination 
in gait, respiratory rate, relative organ weight (e.g., increase in liver, decrease in spleen and thymus), clinical chemistry parameters, and gross pathology (data not shown).

\section{Discussion}

Many of the $(R)$-D chimeric compounds exhibited excellent anticonvulsant activities in the MES model (mice, ip), comparable with the parent compounds $(R)-\mathbf{1}^{11,30}$ and $(S)-\mathbf{2}^{15}\left(\mathrm{ED}_{50}\right.$ $(\mathrm{mg} / \mathrm{kg}):(R)-\mathbf{3},>10,<30 ;(R)-4,5.5 ;(R)-5,9.4 ;(R)-6,14 ;(R)-7, \sim 10 ;(R)-\mathbf{8}, 13 ;(R)-\mathbf{9}, 6.5$; $(R)-1,4.5 ;(S)-2,4.1)$. Furthermore, we observed only modest differences in seizure protection when the $\mathrm{X}$-substitutent in $(R)$-D was varied from electron-withdrawing to electron-donating. Earlier studies on $(R)$-A compounds where the linker $(\mathrm{L})$ was either a single bond ${ }^{9}\left((R)\right.$-E) or an oxymethylene group ${ }^{10}((R)$-F $)$ showed that the electronwithdrawing, trifluoromethoxy $\left(\mathrm{OCF}_{3}\right)$ group provided the greatest protection in the seizure models. For $(R)-\mathbf{D}$, we found the most active compounds to be the $3^{\prime \prime}-\mathrm{F}((R)-4)$ and the $3^{\prime \prime}-$ $\mathrm{OCF}_{3}((R)-9)$ derivatives (MES ED 50 (mice, ip, mg/kg): $(R)-4,5.5 ;(R)-9,6.5 ; \mathrm{MES} \mathrm{ED}_{50}$ (rat, po, $\mathrm{mg} / \mathrm{kg}$ ): $(R)-\mathbf{4},<10 ;(R)-\mathbf{9}, 8.3)$; however, the differences in their activities from the other compounds in the series were not great.
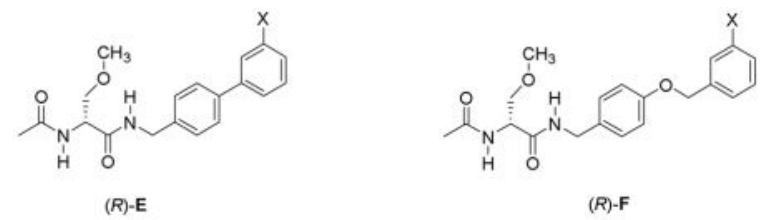

For the $(R)$-E and $(R)$-F chimeric compounds, we determined their slow inactivation $\mathrm{IC}_{50}$ values in CAD cells. ${ }^{9,10}$ Accordingly, we measured the $\mathrm{IC}_{50}$ value for $(R)-\mathbf{9}$ in CAD cells to gauge the relative potency of this series with the two earlier sets of compounds. We found the $(R)-9$ slow inactivation $\mathrm{IC}_{50}(-50 \mathrm{mV})$ value to be $0.70 \mu \mathrm{M}$ (Fig. 5), which is comparable to the values for the corresponding $(R)-\mathbf{E}$ and $(R)$-F derivatives, $(R)-\mathbf{4 0}$ and $(R)-\mathbf{4 1}$, respectively $\left(\mathrm{IC}_{50}(\mu \mathrm{M}):(R)-\mathbf{9}, 0.70 ;(R)-\mathbf{4 0}, 0.85 ;{ }^{9}(R)-\mathbf{4 1}, 0.24^{10}\right)$. Similarly, we found that $(R)-\mathbf{9}$ in CAD cells, like $(R)-\mathbf{4 0} 0^{9}$ and $(R)-\mathbf{4 1},{ }^{10}$ inhibited $\mathrm{Na}^{+}$currents in a frequency (use)-dependent manner, but unlike these two, we observed that $(R)-\mathbf{9}$ affected fast inactivation at the highest concentration $(10 \mu \mathrm{M})$ tested (Fig. 5). These overall results suggest that the composition and size of the different linkers in $(R)-\mathbf{D}-(R)$-F did not appreciably affect the interaction of the chimeric compounds with the VGSCs.
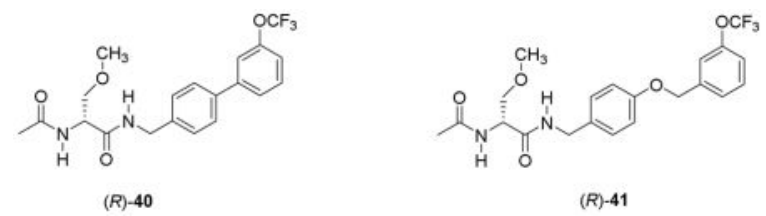

Our finding that $(R)-\mathbf{9}$ promoted sodium channel slow inactivation in rat embryonic cortical neurons that express $\mathrm{Na}_{\mathrm{v}} 1.1, \mathrm{Na}_{\mathrm{v}} 1.2, \mathrm{Na}_{\mathrm{v}} 1.3$, and $\mathrm{Na}_{\mathrm{v}} 1.6$ channels ${ }^{36}$ and in CAD cells that largely express $\mathrm{Na}_{\mathrm{v}} 1.7$ channels ${ }^{9,42,49}$ suggested that this compound showed little $\mathrm{Na}_{\mathrm{v}}$ channel subtype selectivity. We explored this by testing $(R)-\mathbf{9}$ in HEK293 recombinant cells ${ }^{9}$ that expressed $\mathrm{hNa}_{\mathrm{v}} 1.1, \mathrm{rNa}_{\mathrm{v}} 1.3, \mathrm{hNa}_{\mathrm{v}} 1.5$, or $\mathrm{hNa}_{\mathrm{v}} 1.7$ (Fig. 6). In agreement with this 
notion, $(R)-\mathbf{9}(10 \mu \mathrm{M})$ potently transitioned the sodium channels to the slow-inactivated state regardless of the $\mathrm{Na}_{\mathrm{v}}$ channel isoform. In the recombinant cells, we observed that the effect of $(R)-9$ was different on sodium channel fast inactivation and frequency (use)-dependent inhibition. A similar result was previously reported for a $(R)-\mathbf{E}$ compound where $\mathrm{X}=\mathrm{Cl} .{ }^{9}$

The anticonvulsant activities for the $(R)$-D compounds are attributed, in part, to their ability to modulate VGSC activities. Using rat embryonic cortical neurons that express $\mathrm{Na}_{\mathrm{v}} 1.1$, $\mathrm{Na}_{\mathrm{v}} 1.2, \mathrm{Na}_{\mathrm{v}} 1.3$, and $\mathrm{Na}_{\mathrm{v}} 1.6$ channels, ${ }^{40}$ we learned that the $(R)$-D compounds uniformly promoted slow inactivation (Fig. 2). At $10 \mu \mathrm{M}$, the $3^{\prime \prime}$-unsubstituted derivative $(R)-\mathbf{3}$ was the most potent, followed by the $3^{\prime \prime}$-electron-withdrawing derivatives $(R)-\mathbf{4},(R)-\mathbf{5},(R)-\mathbf{9},(R)-\mathbf{7}$, and then the two $3^{\prime \prime}$-electron-donating derivatives $(R)-6$ and $(R)-8$ (Fig. 2C). Interestingly, the relative level of slow inactivation for the (R)-D compounds did not parallel their corresponding anticonvulsant activities. For example, $(R)-\mathbf{3}$ showed the greatest level of slow inactivation (Fig. 2C), but it was the least potent in the MES seizure model in mice (ip) (Table 1). When we compared the slow inactivation $\mathrm{IC}_{50}(-50 \mathrm{mV})$ values for $(R)-\mathbf{9}$ and $(R)-1$ in CAD cells, we found that the $\mathrm{IC}_{50}$ value for $(R)-9$ was $0.70 \mu \mathrm{M}$, which was $\sim 120$ fold lower than the value reported for $(R)-\mathbf{1}(85 \mu \mathrm{M})$. Despite $(R)-9$ 's increased potency, we did not find a comparable increased protection for $(R)-\mathbf{9}$ versus $(R)-\mathbf{1}$ in the MES seizure model in mice (ip) $\left(\mathrm{ED}_{50}(\mathrm{mg} / \mathrm{kg}):(R)-9,6.5 ;(R)-1,4.5\right)$. A similar lack of correspondence for the CAD slow inactivation $\mathrm{IC}_{50}$ values and their in vivo seizure protection activities in the MES test (mice, ip) were observed for the $(R)-\mathbf{E}$ and the $(R)-\mathbf{F}$ compounds with $(R)-\mathbf{1}$ (CAD cells slow inactivation $\mathrm{IC}_{50}(-50 \mathrm{mV}, \mu \mathrm{M}):(R)-\mathbf{4 0}, 0.85 \mu \mathrm{M} ;(R)-\mathbf{4 1}, 0.24 \mu \mathrm{M} ;(R)-\mathbf{1}$, 85; $\left.\mathrm{ED}_{50}(\mathrm{mg} / \mathrm{kg}):(R)-\mathbf{4 0}, 4.7 ;(R)-\mathbf{4 1}, 12 ;(R)-\mathbf{1}, 4.5\right){ }^{9}{ }^{9}, 10$ We tentatively attribute this finding to the multiple factors that contribute to whole animal pharmacological activity, the sodium channel composition in CAD cells versus those in the CNS, the possibility that additional, unidentified pathways exist for seizure control, and the recognition that patchclamp electrophysiology studies do not recapitulate conditions created in the seizure models.

\section{Conclusion}

Many of the chimeric $(R)$-D compounds displayed potent anticonvulsant activities and high PI values, which were similar to ASDs, in the MES test when administered to rodents. The chimeric compounds' anticonvulsant activities likely stemmed, at least in part, from their ability to promote sodium channel slow inactivation. VGSCs are responsible for the initiation of and the sustained activity of neuronal signaling during seizure events. The well described mechanism of action for both $(R)$-D parent compounds, lacosamide and safinamide, involve inhibition of these channels. ${ }^{14,15,37,38}$ Phenytoin, lamotrigine, and carbamazepine are among other ASDs that have primary activity on VGSCs to restrict neuronal firing during seizures. ${ }^{57}$ As evident by perturbation of VGSC slow inactivation (Fig. 2), the class $(R)$-D compounds potently shifted VGSC availability, which readily explains anticonvulsant activity. The type of channel block produced by these compounds is also a desirable characteristic for ASDs. By selectively affecting sodium channel slow inactivation or frequency (use)-dependent block, these compounds can promote channel inhibition in response to sustained use (i.e., epileptic activity). 


\section{Experimental}

\subsection{General methods}

Melting points were determined in open capillary tubes using a Thomas-Hoover melting point apparatus and are uncorrected. Optical rotations were obtained on a Jasco P-1030 polarimeter at the sodium D line $(589 \mathrm{~nm})$ using a $1 \mathrm{dm}$ path length cell. NMR spectra were obtained at $400 \mathrm{MHz}\left({ }^{1} \mathrm{H}\right)$ and $100 \mathrm{MHz}\left({ }^{13} \mathrm{C}\right)$ using TMS as an internal standard. Chemical shifts $(\delta)$ are reported in parts per million ( $\mathrm{ppm})$ from tetramethylsilane. Low-resolution mass spectra were obtained with a BioToF-II-Bruker Daltonics spectrometer by Dr. S. Habibi at the University of North Carolina Department of Chemistry. The high-resolution mass spectrum was performed on a Bruker Apex-Q 12 Telsa FTICR spectrometer by Dr. S. Habibi. Microanalyses were performed by Atlantic Microlab, Inc. (Norcross, GA). Reactions were monitored by analytical thin-layer chromatography (TLC) plates (Aldrich, Cat \# Z12272-6) and analyzed with $254 \mathrm{~nm}$ UV light. The reactions were purified by flash column chromatography using silica gel (Dynamic Adsorbents Inc., Cat \# 02826-25). All chemicals and solvents were reagent grade and used as obtained from commercial sources without further purification. Yields reported are for purified products and were not optimized. Compounds were checked by TLC, ${ }^{1} \mathrm{H}$ and ${ }^{13} \mathrm{C}$ NMR, MS, and elemental analyses. The analytical results are within $\pm 0.40 \%$ of the theoretical value. The TLC, NMR and the analytical data confirmed the purity of the products was $\searrow 95 \%$.

\subsubsection{General procedure for the deprotection and acetylation of $(R)-N$-benzyl} 2- $N$-(tert-butoxycarbonyl)amino-3-methoxypropionamide derivatives $(R)$-34 $(R)$-39 to give $(R)-3$ and $(R)-5-(R)-9$ (Method 1)- $\mathrm{A} \mathrm{CH}_{2} \mathrm{Cl}_{2}$ solution $(0.1-0.3 \mathrm{M})$ of the tert-butoxycarbonyl-compound $((R)-\mathbf{3 4}-(R)-39)$ was treated with $4 \mathrm{M} \mathrm{HCl}$ in dioxane (3-4 equiv) at room temperature (2-12 h). The reaction mixture was evaporated in vacuo. The resulting residue was dissolved in $\mathrm{CH}_{2} \mathrm{Cl}_{2}(0.1-0.3 \mathrm{M})$ and then triethylamine (2-3 equiv) and acetyl chloride (1.0-1.2 equiv) were carefully added at $0{ }^{\circ} \mathrm{C}$ and the resulting solution was stirred at room temperature (2-16 h). The solution was washed with an aqueous $10 \%$ citric acid solution followed by a saturated aqueous $\mathrm{NaHCO}_{3}$ solution. The organic layer was dried $\left(\mathrm{Na}_{2} \mathrm{SO}_{4}\right)$ and concentrated in vacuo. The residue was purified by column chromatography on $\mathrm{SiO}_{2}$ and/or recrystallized with EtOAc/hexanes.

\subsection{2. (R)-N-4' -Phenoxybenzyl 2-N-Acetamido-3-methoxypropionamide ((R)-3)}

—Using Method 1, $(R)-34$ (1.27 g, $3.17 \mathrm{mmol}), 4 \mathrm{M} \mathrm{HCl}(5.6 \mathrm{~mL}), \mathrm{Et}_{3} \mathrm{~N}(962 \mathrm{mg}, 9.51$ $\mathrm{mmol}$ ), and $\mathrm{AcCl}$ (298 $\mathrm{mg}, 3.80 \mathrm{mmol}$ ) gave the desired compound $(R)-\mathbf{3}$ as a white solid (981 mg, 90\%): $R_{f}=0.27\left(20: 1 \mathrm{CH}_{2} \mathrm{Cl}_{2} / \mathrm{MeOH}\right) ; \mathrm{mp} 147-148{ }^{\circ} \mathrm{C} ;[\mathrm{a}]_{\mathrm{D}}{ }^{24}-16.1^{\circ}$ (c 1.0, $\left.\mathrm{CHCl}_{3}\right) ;{ }^{1} \mathrm{H}$ NMR $\left(\mathrm{CDCl}_{3}\right) \delta 2.03\left(\mathrm{~s}, \mathrm{CH}_{3} \mathrm{C}(\mathrm{O})\right), 3.39\left(\mathrm{~s}, \mathrm{OCH}_{3}\right), 3.46(\mathrm{dd}, J=4.3,9.3 \mathrm{~Hz}$, $\left.\mathrm{CHH}^{\prime} \mathrm{OCH}_{3}\right), 3.81\left(\mathrm{dd}, J=4.3,9.3 \mathrm{~Hz}, \mathrm{CHH}^{\prime} \mathrm{OCH}_{3}\right), 4.40-4.48\left(\mathrm{~m}, \mathrm{NHCH}_{2}\right), 4.58$ (dt, $J=$ 4.3, 7.0 Hz, $\left.\mathrm{CHCH}_{2}\right), 6.49$ (d, J = 7.0 Hz, NH), 6.83-6.93 (m, 2 ArH, NH), 6.93-6.97 (m, $\operatorname{ArH}), 7.00(\mathrm{~d}, J=8.2 \mathrm{~Hz}, 2 \mathrm{ArH}), 7.27(\mathrm{~d}, J=8.2 \mathrm{~Hz}, 2 \mathrm{ArH}), 7.32(\mathrm{~m}, 2 \mathrm{ArH})$, addition of excess $(R)-(-)$-mandelic acid to a $\mathrm{CDCl}_{3}$ solution of $(R)-\mathbf{3}$ gave only one signal for the acetyl methyl and one signal for the methoxy protons; ${ }^{13} \mathrm{C} \mathrm{NMR}\left(\mathrm{CDCl}_{3}\right) \delta 23.2$ $\left(\mathrm{C}(\mathrm{O}) \mathbf{C H}_{3}\right), 43.0\left(\mathrm{NHCH}_{2}\right), 52.4\left(\mathrm{CHCH}_{2}\right), 59.1\left(\mathrm{OCH}_{3}\right), 71.6\left(\mathrm{CHCH}_{2}\right), 118.9,119.0$, 123.3, 128.9, 132.7, $156.7(\mathrm{ArC}), 169.9,170.3(2 \mathrm{C}(\mathrm{O}))$, the remaining two aromatic peaks 
were not detected and are believed to overlap with nearby signals; LRMS $\left(\mathrm{ESI}^{+}\right) 365.1$ [M $+\mathrm{Na}]^{+}$(calcd for $\mathrm{C}_{19} \mathrm{H}_{22} \mathrm{~N}_{2} \mathrm{O}_{4} \mathrm{Na}^{+}$365.1); HRMS $\left(\mathrm{ESI}^{+}\right.$) $365.1478[\mathrm{M}+\mathrm{Na}]^{+}$(calcd for $\mathrm{C}_{19} \mathrm{H}_{22} \mathrm{~N}_{2} \mathrm{O}_{4} \mathrm{Na}^{+} 365.1478$ ); Anal. Calcd. for $\mathrm{C}_{19} \mathrm{H}_{22} \mathrm{~N}_{2} \mathrm{O}_{4}$ : C, 66.65; H, 6.48; N, 8.18. Found: C, 66.41; H, 6.36; N, 8.14.

\subsection{3. (R)-N-4' -((3"-Chloro)phenoxy)benzyl 2-N-Acetamido-3-} methoxypropionamide ((R)-5)—Using Method 1, $(R)-35(1.30 \mathrm{~g}, 2.99 \mathrm{mmol}), 4 \mathrm{M} \mathrm{HCl}$ (4.5 mL), $\mathrm{Et}_{3} \mathrm{~N}(908 \mathrm{mg}, 8.97 \mathrm{mmol})$, and $\mathrm{AcCl}(282 \mathrm{mg}, 3.59 \mathrm{mmol})$ gave the desired compound $(R)-5$ as a white solid $(786 \mathrm{mg}, 70 \%): R_{f}=0.29\left(20: 1 \mathrm{CH}_{2} \mathrm{Cl}_{2} / \mathrm{MeOH}\right) ; \mathrm{mp} 129$ $130{ }^{\circ} \mathrm{C} ;[\mathrm{a}]_{\mathrm{D}}{ }^{24}-19.9^{\circ}\left(c 1.0, \mathrm{CHCl}_{3}\right) ;{ }^{1} \mathrm{H} \mathrm{NMR}\left(\mathrm{CDCl}_{3}\right) \delta 2.04\left(\mathrm{~s}, \mathrm{CH}_{3} \mathrm{C}(\mathrm{O})\right), 3.39$ (s, OCH 3 ), 3.41-3.49 (m, $\left.\mathrm{CHH}^{\prime} \mathrm{OCH}_{3}\right), 3.75-3.86\left(\mathrm{~m}, \mathrm{CHH}^{\prime} \mathrm{OCH}_{3}\right), 4.41-4.52\left(\mathrm{~m}, \mathrm{NHCH}_{2}\right)$, 4.52-4.60 (m, $\left.\mathrm{CHCH}_{2}\right), 6.46(\mathrm{~d}, J=7.0 \mathrm{~Hz}, \mathrm{NH}), 6.76-6.85(\mathrm{~m}, \mathrm{ArH}), 6.85-6.91(\mathrm{~m}, \mathrm{NH})$, 6.94-7.03 (m, 3 ArH), 7.05-7.15 (m, ArH), 7.20-7.26 (m, 2 ArH), 7.30-7.37 (m, ArH), addition of excess $(R)-(-)$-mandelic acid to a $\mathrm{CDCl}_{3}$ solution of $(R)-5$ gave only one signal for the acetyl methyl and one signal for the methoxy protons; ${ }^{13} \mathrm{C}$ NMR $\left(\mathrm{CDCl}_{3}\right) \delta 23.1$ $\left(\mathrm{C}(\mathrm{O}) \mathrm{CH}_{3}\right), 42.9\left(\mathrm{NHCH}_{2}\right), 52.5\left(\mathrm{CHCH}_{2}\right), 59.1\left(\mathrm{OCH}_{3}\right), 71.8\left(\mathrm{CHCH}_{2}\right), 116.6,118.9$, 119.5, 123.3, 129.0, 130.5, 132.7, 133.6, 155.6, 158.2 (ArC), 170.0, 170.3 (C(O)); LRMS $\left(\mathrm{ESI}^{+}\right) 377.1[\mathrm{M}+\mathrm{H}]^{+}\left(\right.$calcd for $\left.\mathrm{C}_{19} \mathrm{H}_{21} \mathrm{ClN}_{2} \mathrm{O}_{4} \mathrm{H}^{+} 377.1\right)$; HRMS $\left(\mathrm{ESI}^{+}\right) 377.1269[\mathrm{M}+\mathrm{H}]^{+}$ (calcd for $\mathrm{C}_{19} \mathrm{H}_{21} \mathrm{ClN}_{2} \mathrm{O}_{4} \mathrm{H}^{+}$377.1268); Anal. Calcd. for $\mathrm{C}_{19} \mathrm{H}_{21} \mathrm{ClN}_{2} \mathrm{O}_{4}$ : C, 60.56; H, 5.62; Cl, 9.41; N, 7.43. Found: C, 60.69; H, 5.60; Cl, 9.14; N, 7.32.

\subsection{4. (R)-N-4' -((3"-Methyl)phenoxy)benzyl 2-N-Acetamido-3-}

methoxypropionamide $((\boldsymbol{R})-6)$-Using Method 1, $(R)-36(2.10 \mathrm{~g}, 5.07 \mathrm{mmol}), 4 \mathrm{M} \mathrm{HCl}$ (7.6 mL), $\mathrm{Et}_{3} \mathrm{~N}(1.54 \mathrm{~g}, 15.2 \mathrm{mmol})$, and $\mathrm{AcCl}(447 \mathrm{mg}, 6.08 \mathrm{mmol})$ gave the desired compound $(R)-6$ as a white solid $(1.25 \mathrm{~g}, 69 \%): R_{f}=0.27\left(20: 1 \mathrm{CH}_{2} \mathrm{Cl}_{2} / \mathrm{MeOH}\right) ; \mathrm{mp} 110$ $111^{\circ} \mathrm{C} ;[\mathrm{a}]_{\mathrm{D}}{ }^{24}-19.2^{\circ}\left(c 1.0, \mathrm{CHCl}_{3}\right) ;{ }^{1} \mathrm{H} \mathrm{NMR}\left(\mathrm{CDCl}_{3}\right) \delta 2.05\left(\mathrm{~s}, \mathrm{CH}_{3} \mathrm{C}(\mathrm{O})\right), 2.34(\mathrm{~s}$, $\mathrm{CH}_{3}$ ), 3.39 (s, $\mathrm{OCH}_{3}$ ), 3.42-3.48 (m, $\mathrm{CHH}^{\prime} \mathrm{OCH}_{3}$ ), 3.83 (dd, $J=4.3,9.3 \mathrm{~Hz}, \mathrm{CHH}^{\prime} \mathrm{OCH}_{3}$ ), 4.40-4.52 (m, NHCH $\left.{ }_{2}\right), 4.54-4.57\left(\mathrm{~m}, \mathrm{CHCH}_{2}\right), 6.42$ (d, $\left.J=7.0 \mathrm{~Hz}, \mathrm{NH}\right), 6.68-6.77$ (m, ArH), 6.77-6.85 (m, ArH, NH), 6.90-7.00 (m, $3 \mathrm{ArH})$, 7.18-7.26 (m, $3 \mathrm{ArH})$, addition of excess $(R)-(-)$-mandelic acid to a $\mathrm{CDCl}_{3}$ solution of $(R)-\mathbf{6}$ gave only one signal for the acetyl methyl and one signal for the methoxy protons; ${ }^{13} \mathrm{C} \mathrm{NMR}\left(\mathrm{CDCl}_{3}\right) \delta 21.3\left(\mathrm{ArCH}_{3}\right)$, $23.1\left(\mathrm{C}(\mathrm{O}) \mathbf{C H}_{3}\right), 42.9\left(\mathrm{NHCH}_{2}\right), 52.4\left(\mathrm{CHCH}_{2}\right), 59.0\left(\mathrm{OCH}_{3}\right), 71.8\left(\mathrm{CHCH}_{2}\right), 115.9$, 118.9, 119.5, 124.1, 128.8, 129.4, 132.5, 139.9, 156.7, 157.0 (ArC), 169.9, $170.3(\mathbf{C}(\mathrm{O})$ ); LRMS (ESI $\left.{ }^{+}\right) 357.1[\mathrm{M}+\mathrm{H}]^{+}$(calcd for $\mathrm{C}_{20} \mathrm{H}_{24} \mathrm{~N}_{2} \mathrm{O}_{4} \mathrm{H}^{+} 357.1$ ); HRMS (ESI $\left.{ }^{+}\right) 357.1814$ [M $+\mathrm{H}]^{+}$(calcd for $\mathrm{C}_{20} \mathrm{H}_{24} \mathrm{~N}_{2} \mathrm{O}_{5} \mathrm{H}^{+}$357.1814); Anal. Calcd. for $\mathrm{C}_{20} \mathrm{H}_{24} \mathrm{~N}_{2} \mathrm{O}_{4}: \mathrm{C}, 67.40 ; \mathrm{H}$, $6.79 ; \mathrm{N}, 7.86$. Found: C, 67.34; H, 6.79; N, 7.85.

\subsection{5. (R)- $\mathrm{N}-4^{\prime}$-((3" -Trifluoromethyl)phenoxy)benzyl2-N-Acetamido-3-} methoxypropionamide ((R)-7)-Using Method 1, $(R)-37(1.65 \mathrm{~g}, 3.5 \mathrm{mmol}), 4 \mathrm{M} \mathrm{HCl}$ (4.0 mL), $\mathrm{Et}_{3} \mathrm{~N}(1.07 \mathrm{mg}, 10.6 \mathrm{mmol}), \mathrm{AcCl}(414 \mathrm{mg}, 5.3 \mathrm{mmol})$ gave the desired compound $(R)-7$ as a white solid $(1.23 \mathrm{mg}, 85 \%): R_{f}=0.32\left(20: 1 \mathrm{CH}_{2} \mathrm{Cl}_{2} / \mathrm{MeOH}\right) ; \mathrm{mp} 115-$ $117{ }^{\circ} \mathrm{C} ;[\mathrm{a}]_{\mathrm{D}}{ }^{24}-11.1^{\circ}\left(c 1.0, \mathrm{CHCl}_{3}\right) ;{ }^{1} \mathrm{H} \mathrm{NMR}\left(\mathrm{CDCl}_{3}\right) \delta 2.05\left(\mathrm{~s}, \mathrm{CH}_{3} \mathrm{C}(\mathrm{O})\right), 3.39$ (s, $\left.\mathrm{OCH}_{3}\right), 3.45\left(\mathrm{dd}, J=4.3,9.1 \mathrm{~Hz}, \mathrm{CHH}^{\prime} \mathrm{OCH}_{3}\right), 3.83\left(\mathrm{dd}, J=4.3,9.1 \mathrm{~Hz}, \mathrm{CHH}^{\prime} \mathrm{OCH}_{3}\right.$ ), 4.41-4.52 (m, NHCH 2 ), 4.56 (dt, $J=4.3,6.8 \mathrm{~Hz}, \mathrm{CHCH}_{2}$ ), 6.38-6.50 (m, NH), 6.73-6.85 (m, NH), 6.95-7.04 (m, 2 ArH), 7.06-7.18 (m, 2 ArH), 7.21-7.26 (m, ArH), 7.29 (s, ArH), 
7.32-7.48 (m, $2 \mathrm{ArH})$, addition of excess $(R)-(-)$-mandelic acid to a $\mathrm{CDCl}_{3}$ solution of $(R)-7$ gave only one signal for the acetyl methyl and one signal for the methoxy protons; ${ }^{13} \mathrm{C}$ $\operatorname{NMR}\left(\mathrm{CDCl}_{3}\right) \delta 23.2\left(\mathrm{C}(\mathrm{O}) \mathrm{CH}_{3}\right), 42.9\left(\mathrm{NHCH}_{2}\right), 52.4\left(\mathrm{CHCH}_{2}\right), 59.1\left(\mathrm{OCH}_{3}\right), 71.6$ $\left(\mathrm{CHCH}_{2}\right), 110.0(\mathrm{ArC}), 115.2(\mathrm{q}, J=4.0 \mathrm{~Hz}, \mathrm{ArC}), 119.5,119.6(\mathrm{ArC}), 120.2(\mathrm{q}, J=4.0$ $\mathrm{Hz}, \operatorname{ArC}$ ), 120.7, 121.6, 129.1 (ArC), 131.9 (q, $J=272.0 \mathrm{~Hz}, \mathbf{C F}_{3}$ ), 133.6 (q, $J=32.0 \mathrm{~Hz}$, $\mathrm{ArC}), 155.8(\mathrm{ArC}), 170.0,170.3(\mathbf{C}(\mathrm{O}))$; LRMS $\left(\mathrm{ESI}^{+}\right) 411.2[\mathrm{M}+\mathrm{H}]^{+}$(calcd for $\mathrm{C}_{20} \mathrm{H}_{21} \mathrm{~F}_{3} \mathrm{~N}_{2} \mathrm{O}_{4} \mathrm{H}^{+}$411.2); HRMS (ESI $\left.{ }^{+}\right) 411.1531[\mathrm{M}+\mathrm{H}]^{+}$(calcd for $\mathrm{C}_{20} \mathrm{H}_{21} \mathrm{~F}_{3} \mathrm{~N}_{2} \mathrm{O}_{4} \mathrm{H}^{+}$ 411.1527); Anal. Calcd. for $\mathrm{C}_{20} \mathrm{H}_{21} \mathrm{~F}_{3} \mathrm{~N}_{2} \mathrm{O}_{4} \bullet 0.15 \mathrm{H}_{2} \mathrm{O}: \mathrm{C}, 58.53 ; \mathrm{H}, 5.16 ; \mathrm{F}, 13.89 ; \mathrm{N}$, 6.83. Found: C, 58.15; H, 5.20; F, 13.80; N, 6.78.

\subsection{6. (R)-N-4' -((3" -Methoxy)phenoxy)benzyl 2-N-Acetamido-3-} methoxypropionamide ((R)-8)—Using Method 1, $(R)-38(1.00 \mathrm{~g}, 2.32 \mathrm{mmol}), 4 \mathrm{M} \mathrm{HCl}$ (3.5 mL), $\mathrm{Et}_{3} \mathrm{~N}$ (704 mg, $\left.6.96 \mathrm{mmol}\right)$, and $\mathrm{AcCl}(218 \mathrm{mg}, 2.78 \mathrm{mmol})$ gave the desired compound $(R)-8$ as a white solid $(742 \mathrm{mg}, 86 \%): R_{f}=0.27\left(20: 1 \mathrm{CH}_{2} \mathrm{Cl}_{2} / \mathrm{MeOH}\right) ; \mathrm{mp} 123-$ $124{ }^{\circ} \mathrm{C} ;[\mathrm{a}]_{\mathrm{D}}{ }^{24}-18.8^{\circ}\left(c 1.0, \mathrm{CHCl}_{3}\right) ;{ }^{1} \mathrm{H}$ NMR $\left(\mathrm{CDCl}_{3}\right) \delta 2.04\left(\mathrm{~s}, \mathrm{CH}_{3} \mathrm{C}(\mathrm{O})\right), 3.39$ (s, $\left.\mathrm{OCH}_{3}\right), 3.45\left(\mathrm{t}, J=9.3 \mathrm{~Hz}, \mathrm{CHH}^{\prime} \mathrm{OCH}_{3}\right), 3.78\left(\mathrm{~s}, \mathrm{OCH}_{3}\right), 3.82(\mathrm{dd}, J=4.3,9.3 \mathrm{~Hz}, \mathrm{CHH}$ ' $\left.\mathrm{OCH}_{3}\right), 4.39-4.51\left(\mathrm{~m}, \mathrm{NHCH}_{2}\right), 4.52-4.59\left(\mathrm{~m}, \mathrm{CHCH}_{2}\right), 6.45(\mathrm{~d}, J=7.0 \mathrm{~Hz}, \mathrm{NH}), 6.54-$ 6.60 (m, 2 ArH), 6.63-6.69 (m, ArH), 6.78 (br s, NH), 6.95-7.01 (m, 2 ArH), 7.19-7.26 (m, $3 \mathrm{ArH}$ ), addition of excess $(R)-(-)$-mandelic acid to a $\mathrm{CDCl}_{3}$ solution of $(R)-\mathbf{8}$ gave only one signal for the acetyl methyl and one signal for the methoxy protons; ${ }^{13} \mathrm{C} \mathrm{NMR}\left(\mathrm{CDCl}_{3}\right) \delta$ $23.2\left(\mathrm{C}(\mathrm{O}) \mathbf{C H}_{3}\right), 43.0\left(\mathrm{NHCH}_{2}\right), 52.4\left(\mathrm{CHCH}_{2}\right), 55.3\left(\mathrm{ArOCH}_{3}\right), 59.1\left(\mathrm{OCH}_{3}\right), 71.7$ $\left(\mathrm{CHCH}_{2}\right), 104.9,108.9,110.9,119.2,128.9,130.1,132.8,156.4,158.3,161.0$ (ArC), 169.9, $170.3\left(\mathbf{C}(\mathrm{O})\right.$ ); LRMS (ESI $\left.{ }^{+}\right) 373.2[\mathrm{M}+\mathrm{H}]^{+}\left(\right.$calcd for $\left.\mathrm{C}_{20} \mathrm{H}_{24} \mathrm{~N}_{2} \mathrm{O}_{5} \mathrm{H}^{+} 373.2\right)$; HRMS $\left(\mathrm{ESI}^{+}\right.$) $373.1764[\mathrm{M}+\mathrm{H}]^{+}$(calcd for $\mathrm{C}_{20} \mathrm{H}_{24} \mathrm{~N}_{2} \mathrm{O}_{5} \mathrm{H}^{+}$373.1763); Anal. Calcd. for $\mathrm{C}_{20} \mathrm{H}_{24} \mathrm{~N}_{2} \mathrm{O}_{5}$ : C, 64.50; H, 6.50; N, 7.52. Found: C, 64.51; H, 6.43; N, 7.42.

\subsection{7. (R)- $\mathrm{N}-4^{\prime}-\left(\left(3^{\prime \prime}-\right.\right.$ Trifluoromethoxy)phenoxy)benzyl2-N-Acetamido-3-} methoxypropionamide ((R)-9)—Using Method 1, $(R)-39(1.80 \mathrm{~g}, 3.72 \mathrm{mmol}), 4 \mathrm{M} \mathrm{HCl}$ $(6.0 \mathrm{~mL}), \mathrm{Et}_{3} \mathrm{~N}$ (1.13 g, $\left.11.2 \mathrm{mmol}\right), \mathrm{AcCl}(350 \mathrm{mg}, 4.46 \mathrm{mmol})$ gave the desired compound $(R)-9$ as a white solid $(1.03 \mathrm{~g}, 65 \%): R_{f}=0.27\left(20: 1 \mathrm{CH}_{2} \mathrm{Cl}_{2} / \mathrm{MeOH}\right) ; \mathrm{mp} 108-109{ }^{\circ} \mathrm{C}$; $[\mathrm{a}]_{\mathrm{D}}{ }^{24}-15.1^{\circ}\left(c 1.0, \mathrm{CHCl}_{3}\right) ;{ }^{1} \mathrm{H} \mathrm{NMR}\left(\mathrm{CDCl}_{3}\right) \delta 2.04\left(\mathrm{~s},\left(\mathrm{CH}_{3} \mathrm{C}(\mathrm{O})\right), 3.39\left(\mathrm{~s}, \mathrm{OCH}_{3}\right), 3.45\right.$ (dd, $\left.J=4.3,9.3 \mathrm{~Hz}, \mathrm{CHH}^{\prime} \mathrm{OCH}_{3}\right), 3.82$ (dd, $\left.J=4.1,9.3 \mathrm{~Hz}, \mathrm{CHH}^{\prime} \mathrm{OCH}_{3}\right), 4.39-4.51$ (m, $\left.\mathrm{NHCH}_{2}\right), 4.53-4.57\left(\mathrm{~m}, \mathrm{CHCH}_{2}\right), 6.43(\mathrm{~d}, J=7.0 \mathrm{~Hz}, \mathrm{NH}), 6.70-6.80(\mathrm{~m}, \mathrm{ArH}), 6.98$ (d, $J$ $=8.2 \mathrm{~Hz}, 2 \mathrm{ArH}), 7.08-7.15(\mathrm{~m}, \operatorname{ArH}), 7.23(\mathrm{~d}, J=8.2 \mathrm{~Hz}, 2 \operatorname{ArH}), 7.30-7.38(\mathrm{~m}, 2 \mathrm{ArH})$, addition of excess $(R)-(-)$-mandelic acid to a $\mathrm{CDCl}_{3}$ solution of $(R)-9$ gave only one signal for the acetyl methyl and one signal for the methoxy protons; ${ }^{13} \mathrm{C} \mathrm{NMR}\left(\mathrm{CDCl}_{3}\right) \delta 23.2$ $\left(\mathrm{C}(\mathrm{O}) \mathrm{CH}_{3}\right), 42.9\left(\mathrm{NHCH}_{2}\right), 52.5\left(\mathrm{CHCH}_{2}\right), 59.1\left(\mathrm{OCH}_{3}\right), 71.7\left(\mathrm{CHCH}_{2}\right), 111.3,115.2$, 116.4, 119.6 (ArC), 120.3 (q, $\left.J=257.0 \mathrm{~Hz}, \mathbf{C F}_{3}\right), 129.1,130.5,133.8,150.1,155.5,158.5$ (ArC), 170.0, $170.3(\mathbf{C}(\mathrm{O}))$; LRMS $\left(\mathrm{ESI}^{+}\right) 427.1[\mathrm{M}+\mathrm{H}]^{+}\left(\right.$calcd for $\mathrm{C}_{20} \mathrm{H}_{21} \mathrm{~F}_{3} \mathrm{~N}_{2} \mathrm{O}_{5} \mathrm{H}^{+}$ 427.1); HRMS (ESI $\left.{ }^{+}\right) 427.1486[\mathrm{M}+\mathrm{H}]^{+}\left(\right.$calcd for $\mathrm{C}_{20} \mathrm{H}_{21} \mathrm{~F}_{3} \mathrm{~N}_{2} \mathrm{O}_{5} \mathrm{H}^{+} 427.1481$ ).

\subsection{Pharmacology}

Compounds were screened under the auspices of the National Institutes of Health's ASP. Experiments were performed in male rodents (albino Carworth Farms No. 1 mice (ip), albino Sprague-Dawley rats (ip, po)). Housing, handling, and feeding were in accordance 
with recommendations contained in the Guide for the Care and Use of Laboratory Animals. Anticonvulsant activity was established using the MES test, ${ }^{18} 6 \mathrm{~Hz},{ }^{19}$ and the scMet test, ${ }^{35}$ according to previously reported methods. ${ }^{8,11}$

\subsection{Catecholamine A-differentiated (CAD) cells}

CAD cells were grown at $37^{\circ} \mathrm{C}$ and in $5 \% \mathrm{CO}_{2}$ (Sarstedt, Newton, NC) in Ham's F12/ DMEM (GIBCO, Grand Island, NY), supplemented with $10 \%$ fetal bovine serum (Sigma, St. Louis, MO) and $1 \%$ penicillin/streptomycin (100\% stocks, $10,000 \mathrm{U} / \mathrm{mL}$ penicillin $\mathrm{G}$ sodium and $10,000 \mu \mathrm{g} / \mathrm{mL}$ streptomycin sulfate) ${ }^{49}$ Cells were passaged every $3-5$ days at a 1:5 dilution.

\subsection{Cortical neurons}

Rat cortical neuron cultures were prepared from cortices dissected from embryonic day 19 cortices exactly as described. 58,59

\subsection{Culturing HEK293 cells expressing $\mathrm{Na}_{\mathrm{v}} 1.1, \mathrm{Na}_{\mathrm{v}} 1.3, \mathrm{Na}_{\mathrm{v}} 1.5$, and $\mathrm{Na}_{\mathrm{v}} 1.7$}

$\mathrm{Na}_{\mathrm{v}} 1.1, \mathrm{Na}_{\mathrm{v}} 1.3, \mathrm{Na}_{\mathrm{v}} 1.5$, and $\mathrm{Na}_{\mathrm{v}} 1.7$ stable cells were grown under standard tissue culture conditions $\left(5 \% \mathrm{CO}_{2}\right.$ at $\left.37^{\circ} \mathrm{C}\right)$ in Dulbecco's modified Eagle's medium supplemented with $10 \%$ fetal bovine serum and $1 \%$ penicillin/streptomycin $(100 \%$ stocks, $10,000 \mathrm{U} / \mathrm{mL}$ penicillin G sodium and $10,000 \mu \mathrm{g} / \mathrm{mL}$ streptomycin sulfate) as described before. ${ }^{9}$

\subsection{Electrophysiology}

Whole-cell voltage clamp recordings were performed at room temperature on cortical neurons, CAD cells, and HEK293 cells expressing $\mathrm{Na}_{\mathrm{v}} 1 . \mathrm{x}$ isoforms using an EPC 10 Amplifier (HEKA Electronics, Lambrecht/Pfalz Germany) as described previously., 9,10,20 Electrodes were fabricated from thin-walled borosilicate glass capillaries (Warner Instruments, Hamden, CT) with a P-97 electrode puller (Sutter Instrument, Novato, CA) such that final electrode resistances were 1-2 $\mathrm{M} \Omega$ when filled with internal solutions. The internal solution for recording $\mathrm{Na}^{+}$currents contained (in mM): $110 \mathrm{CsCl}, 5 \mathrm{MgSO}_{4}, 10$ EGTA, 4 ATP Na 2 -ATP, 25 HEPES (pH 7.2, 290-310 mOsm/L). The external solution contained (in $\mathrm{mM}$ ): $100 \mathrm{NaCl}, 10$ tetraethylammonium chloride (TEA-Cl), $1 \mathrm{CaCl}_{2}, 1$ $\mathrm{CdCl}_{2}, 1 \mathrm{MgCl}_{2}, 10$ D-glucose, 4 4-AP, $0.1 \mathrm{NiCl}_{2}, 10$ HEPES (pH 7.3, 310-315 mOsm/L). Whole-cell capacitance and series resistance were compensated with the amplifier. Series resistance error was always compensated to be less than $\pm 3 \mathrm{mV}$. Cells were considered for analysis only when the access resistance was less than $3 \mathrm{M} \Omega$. Linear leak currents were digitally subtracted by $-\mathrm{P} / 4$ leak subtraction.

\subsection{Data acquisition and analysis}

Signals were filtered at $10 \mathrm{kHz}$ and digitized at $10-20 \mathrm{kHz}$. Analysis was performed using Fitmaster and origin8.1 (OriginLab Corporation, MA, USA). For activation curves, conductance $(G)$ through sodium channels was calculated using the equation $G=I /\left(V_{\mathrm{m}}-\right.$ $V_{\text {rev }}$ ), where $V_{\text {rev }}$ is the reversal potential, $V_{\mathrm{m}}$ is the membrane potential at which the current was recorded and $I$ is the peak current. Activation and inactivation curves were fitted to a single-phase Boltzmann function $\mathrm{G} / \mathrm{G}_{\max }=1 /\left\{1+\exp \left[\left(V-V_{50}\right) / k\right]\right\}$, where $\mathrm{G}$ is the peak 
conductance, $\mathrm{G}_{\max }$ is the fitted maximal $\mathrm{G}, V_{50}$ is the half-activation voltage, and $k$ is the slope factor. Additional details of specific pulse protocols are described in the results text or figure legends.

\subsection{Statistical analyses}

Differences between means were compared by either paired or unpaired, two-tailed Student's $t$-tests or an analysis of variance (ANOVA), when comparing multiple groups (repeated measures whenever possible). If a significant difference was determined by ANOVA, then a Dunnett's or Tukey's post-hoc test was performed. Data are expressed as mean \pm SEM, with $\mathrm{p}<0.05$ considered as the level of significance.

\section{Supplementary Material}

Refer to Web version on PubMed Central for supplementary material.

\section{Acknowledgments}

This work is supported by grants, in part, from the NINDS (1 R41 NS080278) and a National Scientist Development Award from the American Heart Association (SDG5280023 to R.K.). T.R.C. is supported by NIH Grant NS053422. We thank the NINDS and the ASP at the National Institutes of Health with Drs. Tracy Chen and John Kehne for kindly performing the pharmacological studies via the ASP's contract site at the University of Utah with Drs. H. Wolfe, H.S. White, and K. Wilcox. We express our appreciation to Dr. Bryan L. Roth and Mr. Jon Evans at the National Institute of Mental Health (NIMH) Psychoactive Drug Screening Project for performing in vitro receptor binding studies. This work was supported by NIMH Psychoactive Drug Screening Program, Contract No. HHSN-271-2008-00025-C (NIMH-PDSP). The NIMH PDSP is directed by Bryan Roth MD, PhD at the University of North Carolina at Chapel Hill and Project Officer Jamie Driscol at NIMH, Bethesda MD, USA. The content is solely the responsibility of the authors and does not represent the official views of the National Center for Research Resources, National Institutes of Health. Harold Kohn has a royalty-stake position in $(R)-\mathbf{1}$ and is the founder of NeuroGate Therapeutics, Inc.

\section{Abbreviations}

$\begin{array}{ll}\text { AAA } & \text { a-aminoamide } \\ \text { ASD } & \text { antiseizure drug } \\ \text { ASP } & \text { Anticonvulsant Screening Program } \\ \text { CAD } & \text { catecholamine A-differentiated } \\ \text { CNS } & \text { central nervous system } \\ \text { ED } 50 & \text { effective dose (50\%) } \\ \text { FAA } & \text { functionalized amino acid } \\ \text { IBCF } & \text { isobutyl chloroformate } \\ \text { IC } 50 & \text { concentration at which half of the channels have transitioned to a slow- } \\ \text { ip } & \text { inactivated state } \\ \text { MAC } & \text { intraperitoneally } \\ \text { MES } & \text { mixed anhydride coupling }\end{array}$


NINDS National Institutes of Neurological Disorders and Stroke

NMM $\quad N$-methylmorpholine

NOAEL no observed adverse effect level

$\mathrm{OCF}_{3}$ trifluoromethoxy

PI protective index

po orally

RMP resting membrane potential

SAR structure activity relationship

scMet scMetrazol

TD $_{50}$ neurological impairment (toxicity, 50\%)

TEA-Cl tetraethylammonium chloride

$V_{1 / 2} \quad$ voltage of half-maximal (in)activation

VGSC voltage-gated sodium channel

\section{References and notes}

1. Centers for Disease Control and Prevention - Epilepsy. [accessed November 5, 2014] http:// www.cdc.gov/epilepsy

2. McNamara, JO. Goodman \& Gilman The Pharmacological Basis of Therapeutics. 11. Brunton, LL.; Lazo, JS.; Parker, KL., editors. Vol. Chapt 19. McGraw-Hill; New York, N.Y: 2006. p. 501-525.

3. Picot MC, Baldy-Moulinier M, Daurs JP, Dujols P, Crespel A. Epilepsia. 2008; 49:1230. [PubMed: 18363709]

4. Begley CE, Lairson DR, Reynolds TF, Coan S. Epilepsy Res. 2001; 47:205. [PubMed: 11738928]

5. Bauer J, Reuber M. Expert Opin Emerg Drugs. 2003; 8:457. [PubMed: 14661999]

6. Schmidt D, Rogawski MA. Epilepsy Res. 2007; 50:71. [PubMed: 12151119]

7. Loscher W, Brandt C. Pharmacol Rev. 2010; 62:688.

8. Salome C, Salome-Grosjean E, Stables JP, Kohn H. J Med Chem. 2010; 53:3756. [PubMed: 20394379]

9. Lee H, Park KD, Torregrosa R, Yang XF, Dustrude ET, Wang Y, Wilson SM, Barbosa C, Xiao Y, Cummins TR, Khanna R, Kohn H. J Med Chem. 2014; 57:6165. [PubMed: 25004277]

10. Park KD, Yang XF, Dustrude ET, Wang Y, Ripsch MS, White FA, Khanna R, Kohn H. ACS Chem Neurosci. 2015; 6:316. [PubMed: 25418676]

11. Choi D, Stables JP, Kohn H. J Med Chem. 1996; 39:1907. [PubMed: 8627614]

12. Pavarello P, Bonsignori A, Dostert P, Heidempergher F, Pinciroli V, Colombo M, McArthur RA, Salvati P, Post C, Fariello RG, Varasi M. J Med Chem. 1998; 41:579. [PubMed: 9484507]

13. Fariello RG. Neurotherap. 2007; 4:110.

14. Perucca E, Yasothan U, Clincke G, Kirkpatrick P. Nat Rev Drug Disc. 2008; 7:973.

15. Fariello RG, McArtur RA, Bonsignori A, Cervini MA, Maj R, Marrari P, Pevarello P, Wolf HH, Woodhead JW, White HS, Varasi M, Salvati P, Post C. J Pharmacol Exp Therap. 1998; 285:397. [PubMed: 9580576]

16. Malek N, Grosset DG. J Exptl Pharmacol. 2012; 4:85.

17. Leonetti F, Capaldi C, Pisani L, Nicolotti O, Muncipinto G, Stefanachi A, Cellamare S, Caccia C, Carotti A. J Med Chem. 2007; 50:4909. [PubMed: 17824599] 
18. White, HS.; Woodhead, JH.; Franklin, MR.; Swinyard, EA.; Wolf, HH. Antiepileptic Drugs. 4. Levy, RH.; Mattson, RH.; Meldrum, BS., editors. Raven Press; N.Y: 1995. p. 99-110.

19. Barton ME, Klein BD, Wolff HH, White HS. Epil Res. 2001; 47:217.

20. Wang Y, Wilson SM, Brittain JM, Ripsch MS, Salome C, Park KD, White AW, Khanna R, Kohn H. ACS Chem Neurosci. 2011; 2:317. [PubMed: 21765969]

21. Kuo CC, Bean BP. Mol Pharmacol. 1994; 46:716. [PubMed: 7969051]

22. Kahlig KK, Hirakawa R, Liu L, George AL Jr, Belardinelli L, Rajamani S. Mol Pharmacol. 2014; 85:162. [PubMed: 24202911]

23. Anderson GW, Zimmerman JE, Callahan FM. J Am Chem Soc. 1967; 87:5012. [PubMed: 6074804]

24. Verkade JG, Urgaonkar S. Org Lett. 2005; 7:3319. [PubMed: 16018650]

25. Chen J, Wang X, Zheng X, Ding J, Liu M, Wu H. Tetrahedron. 2012; 68:8905.

26. Li F, Wang Q, Ding Z, Tao F. Org Lett. 2003; 12:2169. [PubMed: 12790556]

27. Sawyer JS, Schmittling EA, Palkowitz JA, Smith WJ III. J Org Chem. 1998; 63:6338. [PubMed: 11672267]

28. For a comparable procedure for resolving stereoisomers, see: Weisman GR. Morrison JD. Asymmetric Synthesis-Analytical Methods. Academic PressNew York, N.Y1983; 1:153172. Chapter 8

29. Stables, JP.; Kupferberg, HG. Molecular and Cellular Targets for Antiepileptic Drugs. Avanzini, G.; Tanganelli, P.; Avoli, M., editors. John Libbey; London: 1977. p. 191-198.

30. Stoehr T, Kupferberg HJ, Stables JP, Choi D, Harris RH, Kohn H, Walton N, White HS. Epil Res. 2007; 74:147.

31. Porter RJ, Cereghino JJ, Gladding GD, Hessie BJ, Kupferberg HJ, Scoville B, White BG. Cleveland Clin Q. 1984; 51:293.

32. [accessed November 5, 2014] Public Access to Neuroactive \& Anticonvulsant Chemical Evaluations (PANAChE) Database. http://panache@nins.nih.gov

33. Dunham NW, Miya TS. J Am Pharm Assoc. 1957; 46:208.

34. White, HS.; Woodhead, JH.; Wilcox, KS.; Stables, JP.; Kupferberg, HJ.; Wolf, HH. Antiepileptic Drugs. 5. Levy, RH.; Mattson, RH.; Meldrum, BS.; Perruca, E., editors. Lippincott, Williams and Wilkins; Philadelphia, PA: 2002. p. 36-48.

35. Swinyard EA. Epilepsia. 1969; 10:107. [PubMed: 4895510]

36. Salome C, Salome-Grosjean E, Park KD, Morieux P, Swendiman R, DeMarco E, Stables JP, Kohn H. J Med Chem. 2010; 53:1288. [PubMed: 20041718]

37. Errington AC, Stoehr T, Heers AC, Lees G. Mol Pharmacol. 2008; 73:157. [PubMed: 17940193]

38. Sheets PL, Heers C, Stoehr T, Cummins TR. J Pharm Exp Therap. 2008; 326:88.

39. Lee H, Park KD, Yang XF, Dustrude ET, Wilson SM, Khanna R, Kohn H. J Med Chem. 2013; 56:5931. [PubMed: 23772678]

40. Goldin AL. Annu Rev Physiol. 2001; 63:871. [PubMed: 11181979]

41. Wang H, Oxford GS. J Neurophysiol. 2000; 84:2888. [PubMed: 11110818]

42. Wang Y, Brittain JM, Jarecki BW, Park KD, Wilson SM, Wang B, Hale R, Meroueh SO, Cummins TR, Khanna RJ. Biol Chem. 2010; 285:25296.

43. Hodgkin AL, Huxley AF. J Physiol. 1952; 116:497. [PubMed: 14946715]

44. Rudy B. J Physiol. 1978; 283:1. [PubMed: 722569]

45. Bean BP. Nat Rev Neurosci. 2007; 8:451. [PubMed: 17514198]

46. Do MTH, Bean BP. Neuron. 2003; 39:109. [PubMed: 12848936]

47. Vilin YY, Ruben PC. Cell Biochem Biophys. 2001; 35:111.

48. Errington AC, Stohr T, Lees G. Curr Top Med Chem. 2005; 5:15. [PubMed: 15638775]

49. Wang Y, Park KD, Salome C, Wilson SM, Stables JP, Liu R, Khanna R, Kohn H. ACS Chem Neurosci. 2011; 2:90. [PubMed: 21532923]

50. Errington AC, Stohr T, Heers C, Lees G. Mol Pharmacol. 2008; 73:157. [PubMed: 17940193]

51. Catterall WA. Novartis Found Symp. 2002; 241:206. discussion 218. [PubMed: 11771647]

Bioorg Med Chem. Author manuscript; available in PMC 2016 July 01. 
52. Rowley NM, White HS. Epil Res. 2010; 92:163.

53. Morimoto K, Fahnestock M, Racine RJ. Prog Neurobiol. 2004; 73:1. [PubMed: 15193778]

54. Lothman EW, Williamson JM. Brain Res. 1994; 649:71. [PubMed: 7953657]

55. White HS. Epilepsia. 2003; 44(Suppl 7):2. [PubMed: 12919332]

56. UNC's NIMH Psychoactive Drug Screening Program. http://pdsp.med.unc.edu

57. Bialer M, Johannessen SI, Kupferberg HJ, Levy RH, Loiseau P, Percucca E. Epil Res. 2002; 51:31.

58. Brittain JM, Piekarz AD, Wang Y, Kondo T, Cummins TR, Khanna R. J Biol Chem. 2009; 284:31375. [PubMed: 19755421]

59. Brittain JM, Wang Y, Eruvwetere O, Khanna R. FEBS Lett. 2012; 586:3813. [PubMed: 23022559] 


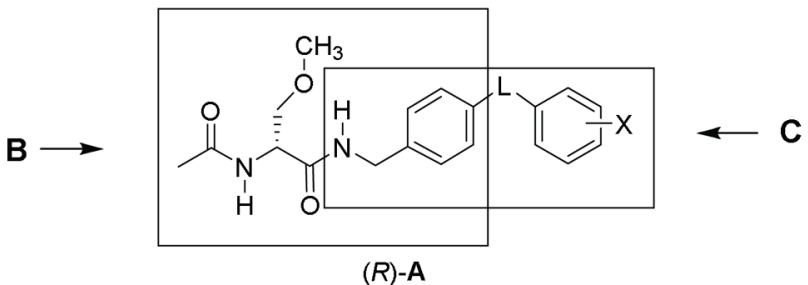

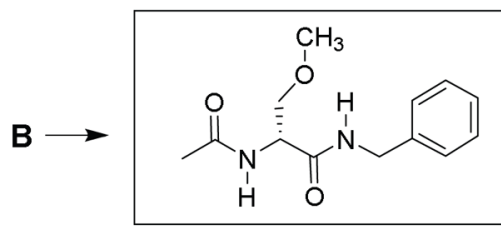

(R)-1 (lacosamide)

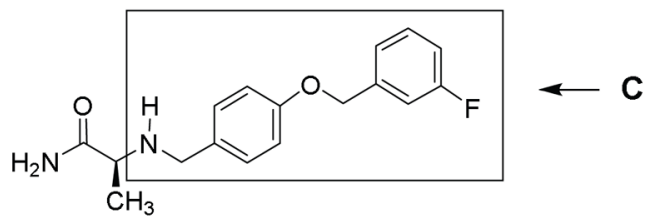

(S)-2 (safinamide)

Figure 1. Generation of chimeric class $(R)$-A from $(R)$-l and $(S)-2$

Box $\mathbf{B}$ represents lacosamide $((R)-\mathbf{1})$ and Box $\mathbf{C}$ represents safinamide $((S)-2)$ derived component. 

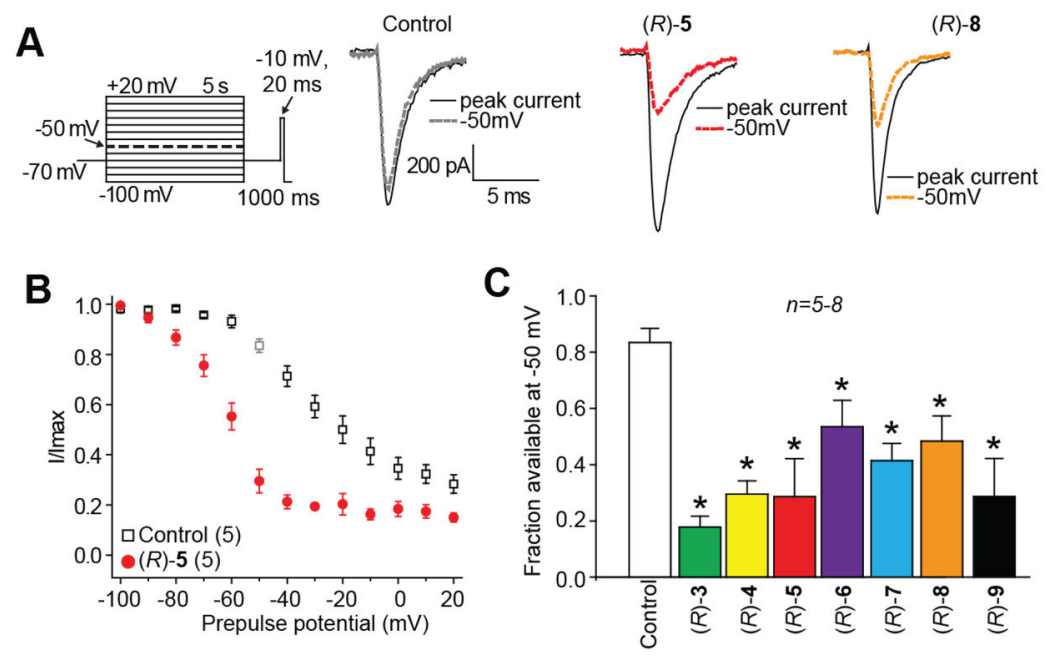

Figure 2. Effects of $(R)-3$ - $(R)-9$ on steady-state slow inactivation state of $\mathrm{Na}^{+}$currents in embryonic cortical neurons

A. Voltage protocol for slow inactivation. Currents were evoked by 5 s prepulses between $-100 \mathrm{mV}$ and $+20 \mathrm{mV}$ (in $10 \mathrm{mV}$ increments), and then fast-inactivated channels were allowed to recover for $1000 \mathrm{~ms}$ at a hyperpolarized pulse to $-70 \mathrm{mV}$ before testing for the fraction of available channels for $20 \mathrm{~ms}$ at $-10 \mathrm{mV}$. The fraction of channels available at $-10 \mathrm{mV}$ was analyzed. Representative current traces from cortical neurons in the absence (control, $0.1 \%$ DMSO) or presence of $10 \mu \mathrm{M}(R)-\mathbf{5}$ or $(R)-8$ are illustrated. The black and dashed traces represent the currents evoked at -100 and $-50 \mathrm{mV}$, respectively (also highlighted in the voltage protocol as a dashed line). B. Summary of steady-state slow activation curves for neurons treated with DMSO (control) or $10 \mu \mathrm{M}(R)$-5. Significant druginduced slow inactivation was evident at voltages more depolarizing that $-80 \mathrm{mV}$ in neurons treated with $(R)-5$. C. Summary of the fraction of current available at $-50 \mathrm{mV}$ for neurons treated with $0.1 \%$ DMSO (control) or $10 \mu \mathrm{M}$ of the indicated compounds. Asterisks (*) indicate statistically significant differences in fraction of current available between control and the indicated compounds $(\mathrm{p}<0.05$, Student's t-test). Data are from 5-8 cells per condition. 


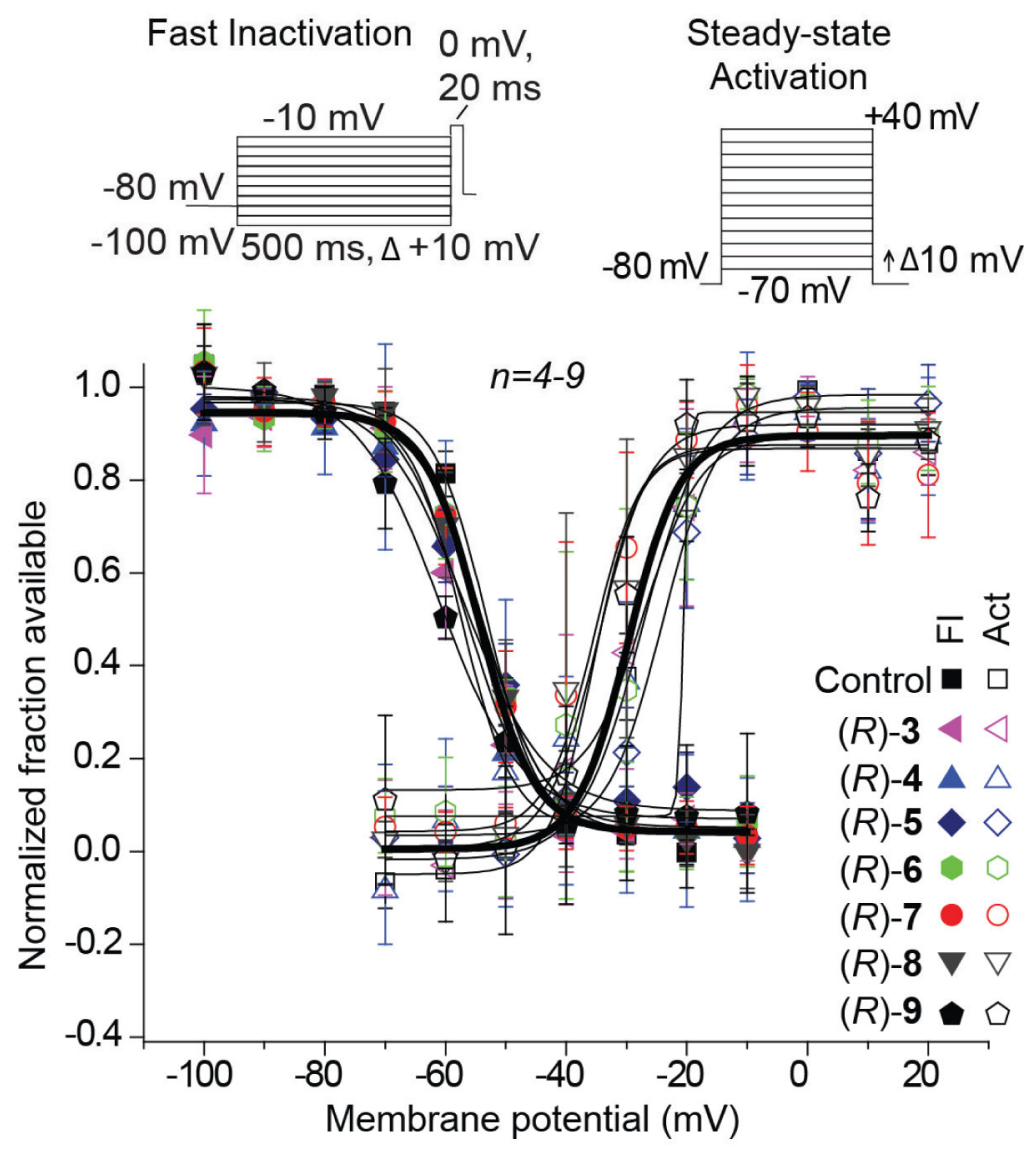

Figure 3. Effects of $(R)-3$ - $(R)-9$ on fast inactivation and steady-state activation states of $\mathrm{Na}^{+}$ currents in embryonic cortical neurons

Voltage protocol for fast inactivation (top left) and activation (top right). Representative Boltzmann fits for steady-state fast inactivation and activation for cortical neurons treated with $0.1 \%$ DMSO (control, bolded curves) and the indicated compounds are shown. Values for $V_{1 / 2}$, the voltage of half-maximal inactivation and activation and the slope factors $(k)$ were derived from Boltzmann distribution fits to the individual recordings and averaged to determine the mean $( \pm$ SEM) voltage dependence of steady-state inactivation and activation, respectively. No significant differences were observed between control and fast inactivation or activation other than for $(R)-7$ and $(R)-8$ for any of the conditions tested ( $\mathrm{p}>0.05$, oneway ANOVA). Data are from 5-7 cells per condition. 

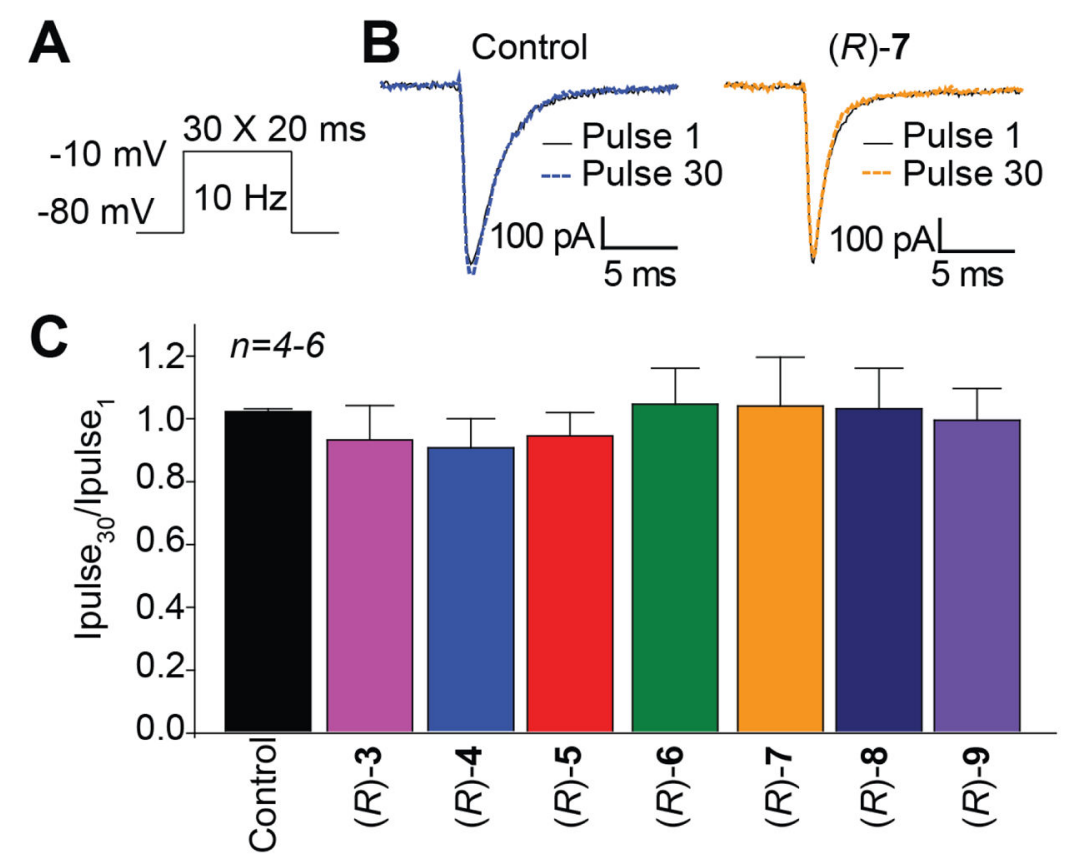

Figure 4. Effects of $(R)-3$ - $(R)-9$ on frequency (use)-dependent block of $\mathrm{Na}^{+}$currents in embryonic cortical neurons

A. The frequency (use)-dependence of block was examined by holding cells at the hyperpolarized potential of $-80 \mathrm{mV}$ and evoking currents at $10 \mathrm{~Hz}$ by $20 \mathrm{~ms}$ test pulses to $-10 \mathrm{mV}$. B. Representative overlaid traces are illustrated by pulses 1 and 30 for control $(0.1 \%$ DMSO $)$ and in the presence of $(R)-7(10 \mu \mathrm{M})$. C. Summary of the maximal decrement in current amplitude observed at the end of the 30-pulse train for control or $10 \mu \mathrm{M}$ of the indicated compounds. None of the compounds exhibited any degree of frequency (use)dependence ( $p>0.05$, one-way ANOVA with Dunnett's post-hoc test). Data are from 4-6 cells per condition. 

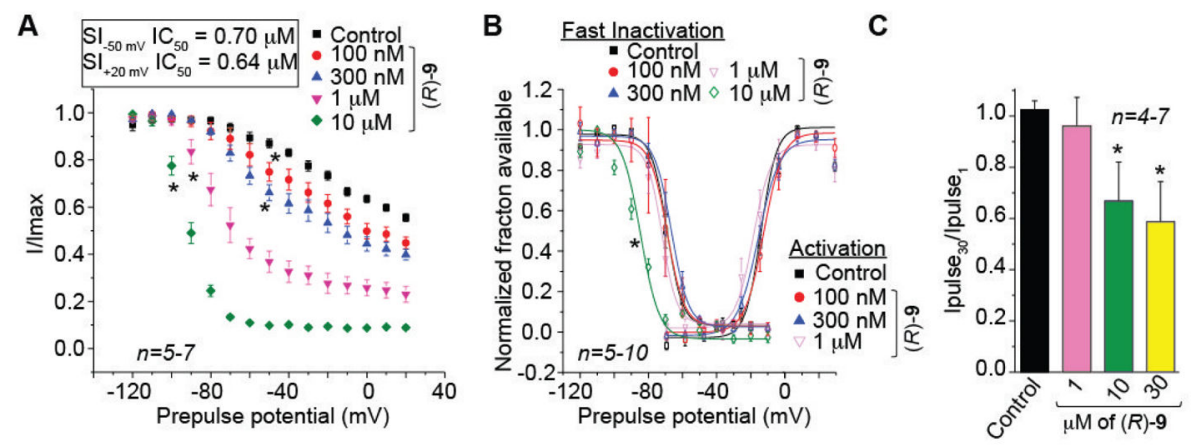

Figure 5. Effects of $(R)-9$ on electrophysiological properties of $\mathrm{Na}^{+}$currents in CAD cells A. Summary of steady-state slow activation curves for CAD cells treated with $0.1 \%$ DMSO (control) or the indicated concentrations of $(R)-9$. Significant $(R)$-9-induced slow inactivation was evident; the starting voltages at which the extent of slow inactivation was significantly different from control are indicated by asterisks $(*, p<0.05$, Student's t-test versus control). B. Representative Boltzmann fits for steady-state fast inactivation and activation for CAD cells treated with $0.1 \%$ DMSO (control) and various concentrations of $(R)-9$ are shown. Values for $V_{1 / 2}$, the voltage of half-maximal inactivation and activation and the slope factors $(k)$ were derived from Boltzmann distribution fits to the individual recordings and averaged to determine the mean ( \pm SEM) voltage dependence of steady-state inactivation and activation, respectively. Statistically significant differences between control and fast inactivation for $10 \mu \mathrm{M}(R)-9$ are indicated by the asterisk ${ }^{*}, \mathrm{p}<0.05$, one-way ANOVA). C. Summary of the maximal decrement in current amplitude observed at the end of the 30-pulse train for control or 1,10 , or $30 \mu \mathrm{M}$ of $(R)-9$. The two highest concentrations of $(R)-9$ induced significant frequency (use)-dependence compared to control ( $\mathrm{p}>0.05$, oneway ANOVA with Dunnett's post-hoc test). Data are from 4-10 cells per condition as indicated. 

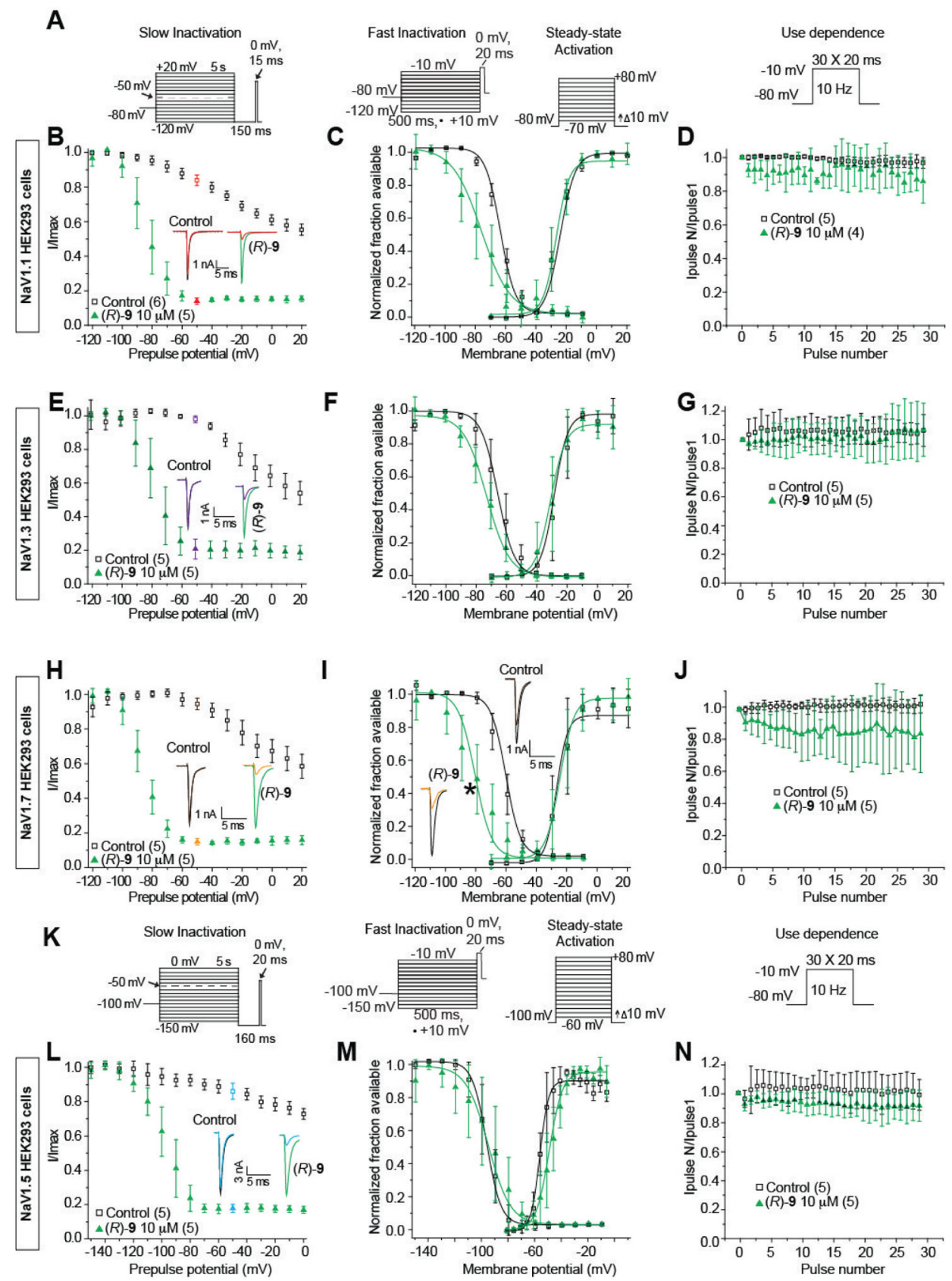

Figure 6. Analysis of $(R)-9$ on electrophysiological properties of $\mathrm{Na}_{\mathrm{v}} 1.1, \mathrm{Na}_{\mathrm{v}} 1.3, \mathrm{Na}_{\mathrm{v}} 1.7$, and $\mathrm{Na}_{\mathbf{v}} 1.5$ currents in HEK293 cells

A, K. Voltage protocols for examining slow inactivation, fast inactivation, steady-state activation and frequency (use)-dependent block. $\mathrm{Na}_{\mathrm{v}} 1.5$ uses hyperpolarized protocols due to differences in the hyperpolarized activation typical for this isoform. B, E, H, L. Summary of steady-state slow activation curves for HEK293 cells treated with $0.1 \%$ DMSO (control) or $10 \mu \mathrm{M}(R)-9$. Insets illustrate representative current traces from HEK293 cells in the absence (control, 0.1\% DMSO) or presence of $10 \mu \mathrm{M}(R)-9$. Traces represent the currents evoked at -120 (black or green) and $-50 \mathrm{mV}$ (red, purple, orange, or cyan). C, F, I, M. 
Representative Boltzmann fits for steady-state fast inactivation and activation for HEK293 cells treated with $0.1 \%$ DMSO (control) or $10 \mu \mathrm{M}$ of $(R)-9$. Values for $V_{1 / 2}$, the voltage of half-maximal inactivation and activation, and the slope factors $(k)$ were derived from Boltzmann distribution fits to the individual recordings and were averaged to determine the mean ( \pm SEM) voltage dependence of steady-state inactivation and activation, respectively. (R)-9 significantly shifted the $\mathrm{V}_{1 / 2}$ of fast inactivation for $\mathrm{Na}_{\mathrm{v}} 1.7$ by $\sim 20.2 \mathrm{mV}$ in the hyperpolarizing direction $\left(^{*}, \mathrm{p}<0.05\right.$, Student's t-test versus control) while the $\mathrm{V}_{1 / 2} \mathrm{~s}$ for $\mathrm{Na}_{\mathrm{v}} 1.1, \mathrm{Na}_{\mathrm{v}} 1.3$, and $\mathrm{Na}_{\mathrm{v}} 1.5$ were not affected. $\mathbf{D}, \mathbf{G}, \mathbf{J}, \mathbf{N}$. Summary of average frequency (use)-dependent decrease in current amplitude over time ( \pm SEM) produced by control $(0.1 \%$ DMSO) or $10 \mu \mathrm{M}(R)-9$. Data are from 5-6 cells per condition. 


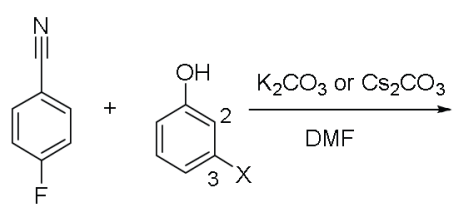

10
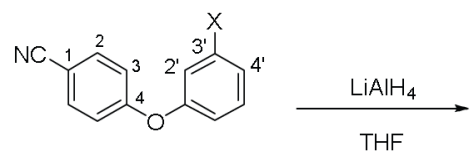

16: $\mathrm{X}=\mathrm{Cl}$

17; $\mathrm{X}=\mathrm{CH}_{3}$

18, $\mathrm{X}=\mathrm{CF}_{3}$

19. $\mathrm{X}=\mathrm{OCH}_{3}$

20, $\mathrm{X}=\mathrm{OCF}_{3}$

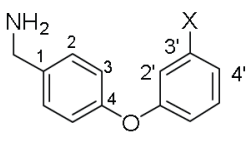

21; $\mathrm{X}=\mathrm{H}$

22, $\mathrm{X}=\mathrm{Cl}$

23: $\mathrm{X}=\mathrm{CH}_{3}$

24, $\mathrm{X}=\mathrm{CF}_{3}$

25, $\mathrm{X}=\mathrm{OCH}_{3}$

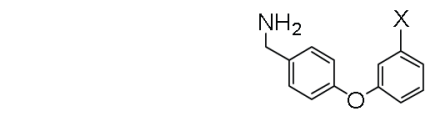

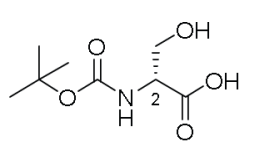

(R)-27

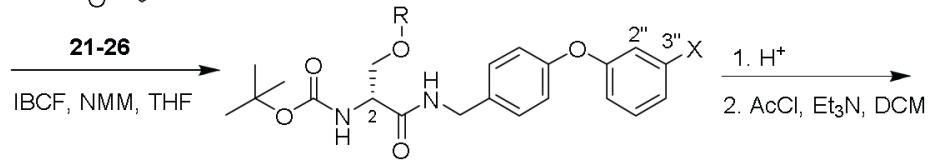

(R)-28; $\mathrm{R}=\mathrm{H}, \mathrm{X}=\mathrm{H}$

(R)-29; $\mathrm{R}=\mathrm{H}, \mathrm{X}=\mathrm{Cl}$

(R)-30; $\mathrm{R}=\mathrm{H}, \mathrm{X}=\mathrm{CH}_{3}$

$\begin{array}{ll}(R)-31 ; & \mathrm{R}=\mathrm{H}, \mathrm{X}=\mathrm{CF}_{3} \\ & (R)-32 ; \mathrm{R}=\mathrm{H}, \mathrm{X}=\mathrm{OCH}_{3} \\ \mathrm{Ag}_{2} \mathrm{O}, \mathrm{CH}_{3} \mathrm{CN} & (R)-33 ; \mathrm{R}=\mathrm{H}, \mathrm{X}=\mathrm{OCF}_{3} \\ \mathrm{CH}_{3} \mathrm{I} & \end{array}$

(R)-34; $\mathrm{R}=\mathrm{CH}_{3}, \mathrm{X}=\mathrm{H}$

(R)-35; $\mathrm{R}=\mathrm{CH}_{3}, \mathrm{X}=\mathrm{Cl}$

(R)-36; $\mathrm{R}=\mathrm{CH}_{3}, \mathrm{X}=\mathrm{CH}_{3}$

(R) $-37 ; \mathrm{R}=\mathrm{CH}_{3}, \mathrm{X}=\mathrm{CF}_{3}$

$(R)$-38; $\mathrm{R}=\mathrm{CH}_{3}, \mathrm{X}=\mathrm{OCH}_{3}$

(R)-39; R $=\mathrm{CH}_{3}, \mathrm{X}=\mathrm{OCF}_{3}$

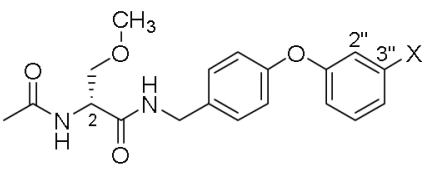

(R)-3; $\quad \mathrm{X}=\mathrm{H}$

(R) $-5 ; \quad X=\mathrm{Cl}$

(R) $-6 ; \quad \mathrm{X}=\mathrm{CH}_{3}$

(R)-7; $\quad \mathrm{X}=\mathrm{CF}_{3}$

(R)-8; $\mathrm{X}=\mathrm{OCH}_{3}$

(R) $-9 ; \quad X=\mathrm{OCF}_{3}$

Scheme 1.

Synthesis of $(R)-\mathbf{3}$ and $(R)-5-(R)-9$ 


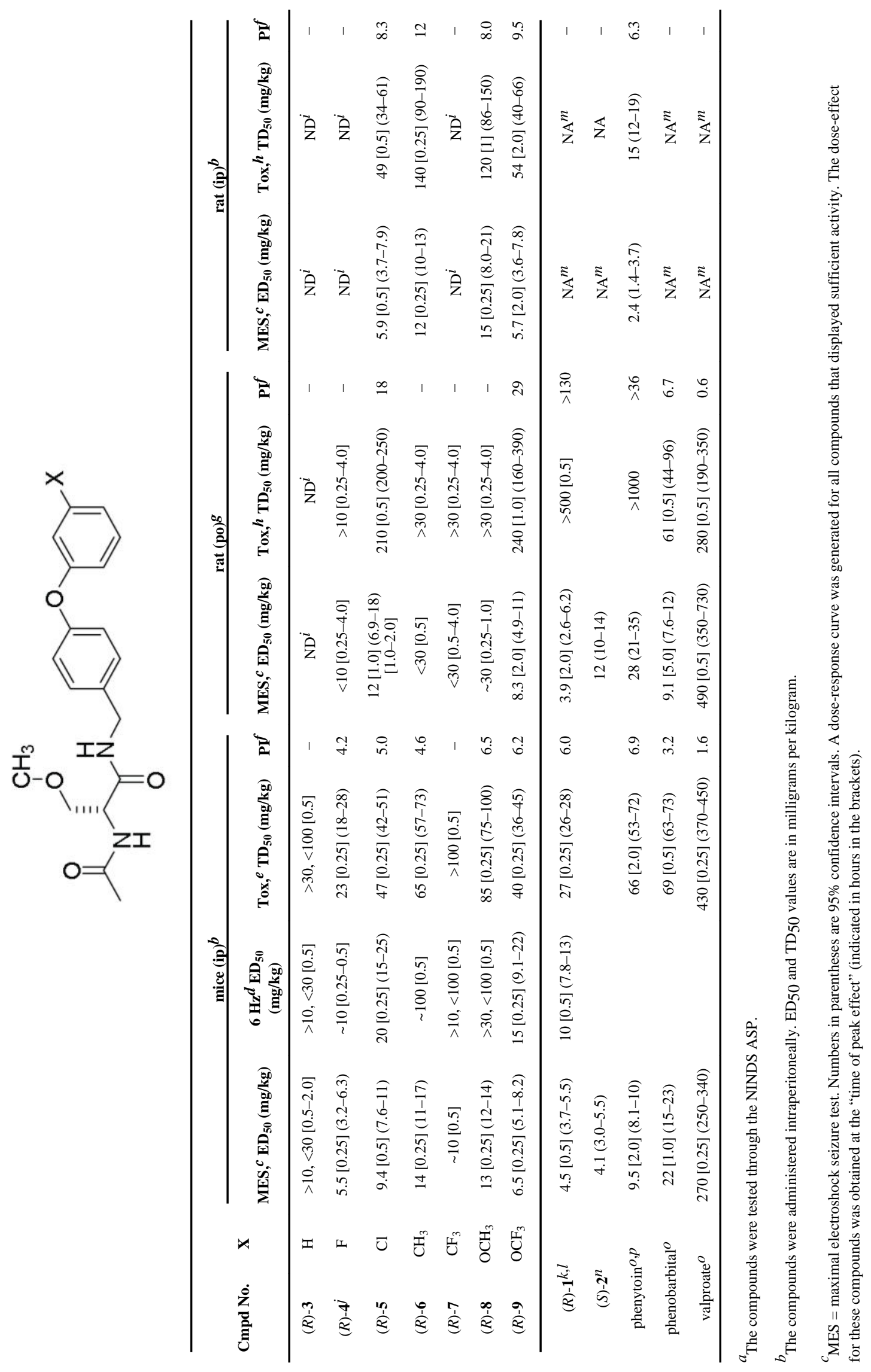

Bioorg Med Chem. Author manuscript; available in PMC 2016 July 01. 


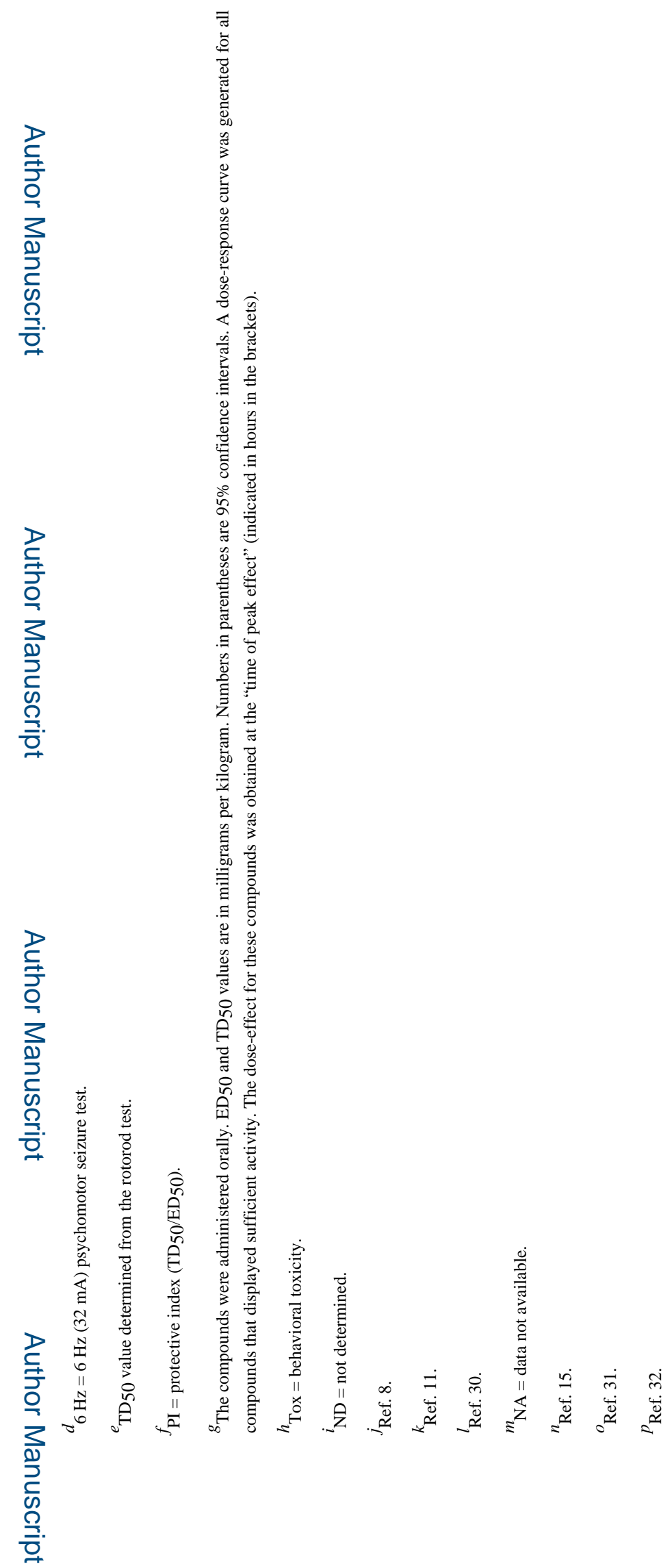

Bioorg Med Chem. Author manuscript; available in PMC 2016 July 01. 


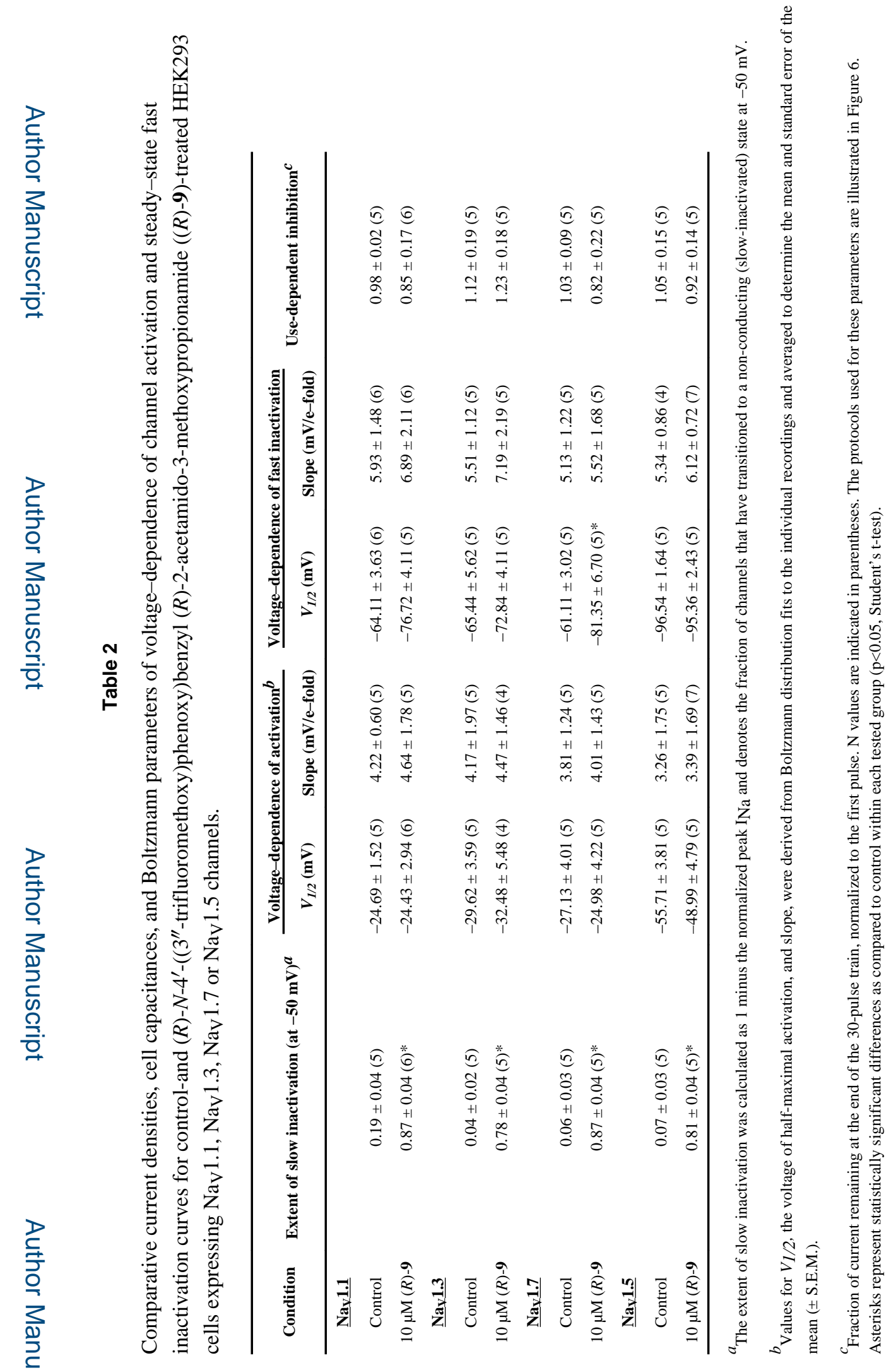

Bioorg Med Chem. Author manuscript; available in PMC 2016 July 01. 